\title{
Gásir in Eyjafjörður: International Exchange and Local Economy in Medieval Iceland
}

\author{
Ramona Harrison ${ }^{1, *}$, Howell M. Roberts², and W. Paul Adderley ${ }^{3}$
}

\begin{abstract}
The site of Gásir in Eyjafjörður in northeast Iceland was excavated from 2001-2006, revealing details of one of the larger seasonal trading centers of medieval Iceland. Interdisciplinary investigations of the site have shed light upon the organization of the site and provided confirmation of documentary accounts of both prestige items (gyrfalcons, walrus ivory) and bulk goods (sulphur) concentrated for export. Gásir was a major point of cultural contact as well as economic exchange between Icelanders and the world of medieval Europe, and the zooarchaeological analyses indicated a mix of foodways and the presence of exotic animals and a well-developed provisioning system, which supplied high-quality meat and fresh fish to the traders. The excavations demonstrated an unexpected regional-level economic impact of the seasonally occupied site on the surrounding rural countryside, and contribute to ongoing investigations of the extent and impact of overseas trade in medieval Iceland.
\end{abstract}

\section{Introduction}

The settlement of the North Atlantic islands during the Viking Age (ca AD 750-1050) has long been seen primarily as a search by Nordic chieftains and their followers for new farming settlements, with island colonization spurred on by competition and conflict among chiefs in the Scandinavian homelands (e.g., Karlsson 2000:15) The dispersed settlement pattern of individual farmsteads that developed in Iceland and Greenland by the $11^{\text {th }}$ century (without villages or hamlets such as developed in the Faroe Islands and in some parts of the Orkneys) would seem to support the primacy of agricultural production and subsistence uses of a range of wild resources in the economic choices that created Icelandic cultural landscapes (Vésteinsson 2000, Vésteinsson et al. 2003). Documentary sources from the 12th-14th centuries (based in part upon earlier oral tradition) describe this initial settlement, emphasizing the role of chieftains in claiming agricultural land and controlling access to fishing grounds, sealing beaches, whale and timber strandings, and similar local resource zones, rather than primarily engaging in overseas trade and exchange (Kristjánsson 1985-1988, Sigurðsson 1999). While the mainly $13^{\text {th }}$-century Icelandic sagas mention foreign traders and Icelandic overseas trading ventures, these references are hard to interpret in any quantitative fashion, although thorough attempts to tackle this issue were made by Melsteð (1895, 1907-15, 1916-30). The problem is that the Icelandic sagas tend to use these overseas contacts as conventions to advance plot lines or demonstrate the wide contacts and prestige of particular personages. The actual extent and economic importance of both internal and external trade and exchange in Viking Age and Medieval Iceland has long been controversial, with some authors using the documentary sources to model very extensive overseas trading contacts in the early Middle Ages (for this traditional view see, i.e., Jóhannesson 1974), while a more recent approach (not always based on primary data) models a far more self-contained and somewhat inward-looking society (i.e., Durrenberger and Pálsson 1989, Gelsinger 1981, Hastrup 1990). Archaeology and paleoecology are playing an increasing role in expanding our understanding of economy, settlement, and human environmental impact in Iceland and the region as a whole, and it is now possible to significantly supplement the written record and contribute to a debate previously based largely upon written sources (e.g., Adderley and Simpson 2005, 2006; McGovern et al. 2007; Simpson et al. 2002; Vésteinsson et al. 2003).

One important recent archaeological finding has been evidence for an extensive inter-regional exchange in processed fish (probably both round dried and flat dried) within Iceland dating back to the initial settlement in the late $9^{\text {th }}$ century (Perdikaris and McGovern 2007, 2008). The presence of large amounts of marine fish bone as well as some seamammal bone and sea-bird bones and eggs on inland sites in several parts of Iceland (McGovern et al. 2006) combined with the wealth and importance of Viking Age sites with excellent fishing access but limited agricultural land in the mountainous North West peninsula (Edvardsson and McGovern 2005) have led archaeologists to model a well-developed Viking Age staple-goods exchange network in Iceland. This well-organized exchange system pre-dates the major expansion of commercial cod fishing in the eastern North Atlantic ca 950-1100 now documented by both zooarchaeology and

${ }^{1}$ CUNY Doctoral Program in Anthropology, Department of Anthropology, CUNY Graduate School, 365 Fifth Avenue, New York, NY 10016. ${ }^{2}$ Fornleifastofnun Íslands, Icelandic Archaeology Institute, Bárugata 3, 101 Reykjavík, Iceland. ${ }^{3}$ School of Biological and Environmental Sciences, University of Stirling, Stirling FK9 4LA, Scotland, UK. ${ }^{*}$ Corresponding author -ramonaharrison@yahoo.com. 
written sources (Amundsen et al. 2005, Barrett and Richards 2004, Barrett et al. 2004, Krivogorskaya 2005, Perdikaris 1999). Growing evidence for early intra-island exchange of dried fish products prior to the $12^{\text {th }}$-century commercial fishing expansion thus raises questions about the undocumented role of inter-island fish trading and its role in the initial settlement process.

New perspectives are also developing on the potential role of Viking-age walrus hunters in the colonization of both Iceland and Greenland, driven in part by new finds of walrus bones in both archaeological and paleontological contexts in Iceland (Dugmore et al. 2007, Vésteinsson 2006). The documentation of a medieval entrepôt site at Sandhavn in southwestern Greenland (Christiansen 2002) and additional finds of walrus-tusk processing debris in all levels of stratified contexts on Norse sites in both major Greenlandic settlement areas (Ogilvie et al., in prep.; Smiarowski et al. 2007) further underlines the potential role of local and regional exchange in shaping island economies, and may also suggest how much more remains to be learned about long-distance trade in the early North Atlantic.

This paper seeks to provide an interdisciplinary perspective on the nature and extent of later medieval international trade from Iceland by including potential interaction between a seasonal trading site and its hinterlands. Focus is upon the results of archaeological investigations at the seasonal trading site of Gásir in northeast Iceland, providing both an overview of the organization of the later occupation phases (mainly $14^{\text {th }}$ century AD) and attempting to place the site in a wider context.

Gásir was a highly specialized site in its structure and layout, as a collection point and perhaps site of final finishing of Icelandic (and other North Atlantic) products for export and import, and as a regular point of cultural contact between rural Iceland and urban Europe. Collaborative interdisciplinary investigation suggests that Gásir's economic and social impact upon the surrounding Icelandic society may have been more important than its casual and impermanent architecture would suggest.

\section{Gásir in Eyjafjörður: The Excavation Site}

The Gásir site lies in at the western side of Eyjafjörður, northeast Iceland (Fig. 1), close to the modern city of Akureyri. The site has been previously investigated by the Dane Premierløjtnant Froda in 1902 on behalf of Daniel Bruun and excavated by Bruun and Finnur Jónsson in 1907 (Bruun and Jónsson 1908). Margrét Hermanns-Auðardóttir and Bjarni F. Einarsson dug 4 trenches, 3 x 1 m, in 1986, which indicated the complexity of at least two groups of well-preserved earthen structures and the remains of a church that was also investigated originally by Bruun and Jónsson (1908) and is set within a large circular churchyard enclosure (Roberts et al. 2005, 2006). Following a topographical and geophysical survey (Horsley, in Roberts et al. 2002a:32-38), a re-excavation of Bruun and Jónsson's pits and 3 of the 1986 trenches in 2001 (Roberts et al. 2002a), and a search of Daniel Bruun's archives held at the Danish National Museum (Copenhagen), a major excavation by the Institute of Archaeology in Iceland (FSí) under commission from the Akureyri Museum commenced in 2001 and concluded in 2006. During this excavation, the site was divided into several areas, each bearing evidence of different activities in the later Middle Ages. The overall open-area excavation strategy aimed at recovering a broad synchronic picture of conditions on the site in its later phases ( $14^{\text {th }}$ to possibly early $15^{\text {th }}$ century), expanding in phase over a wider area rather than producing a narrow deep multiphase pit; the artifacts and ecofacts collected are thus all from the same broad time period. While much work can still be done at the site, the 2001-06 investigations provide a solid basis for discussion of the high-medieval $14^{\text {th }}$-century phase of occupation and for the spatial correlation and connection of features, structures, and open spaces. The site's structures (Figs. 2, 3) are largely composed of interlinked, sunken-featured buildings ("booths") and open activity areas of various sizes. Fireplaces, dwelling areas, workshops, and trackways as well as storage pits and garbage dumps have yielded bones, tools, pottery, and other remains (including a unique concentration of raw sulphur) that allow interpretation of activities at the site during each market season (Roberts et al. 2004, 2006). The booth buildings were cut into the natural ground as sunken features, and rudimentary standing walls were heightened by stacked turf blocks (Roberts et al. 2006). Consecutive use and disuse of these enclosed spaces left thin occupational deposits divided by lenses of windblown sand and silt

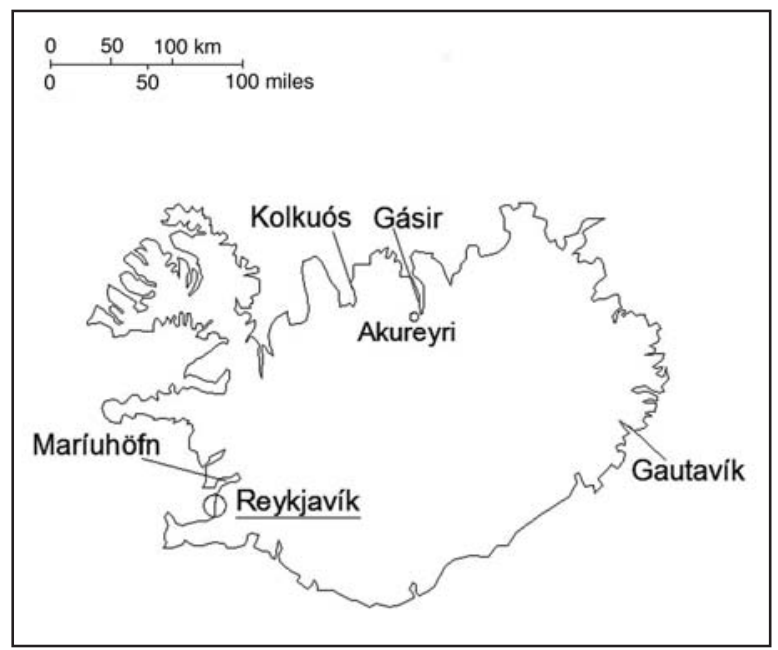

Figure 1. Location map. 
Figure 2. Gásir site layout (from Roberts et al. 2006).

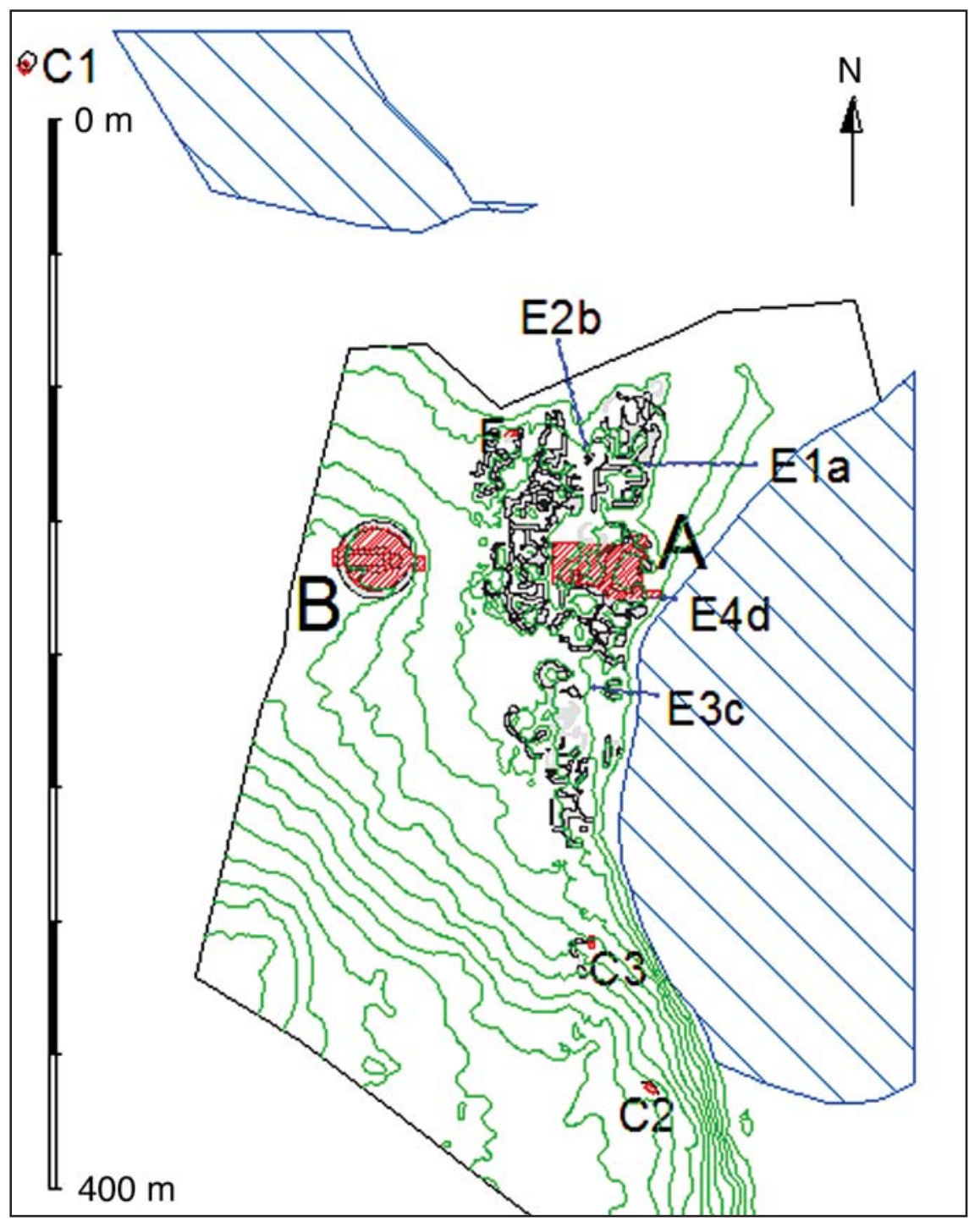

Figure 3. Layout of the two main excavation areas: A. the booth structures, and B. the churchyard. Various features discussed are annotated (from Roberts et al. 2006).

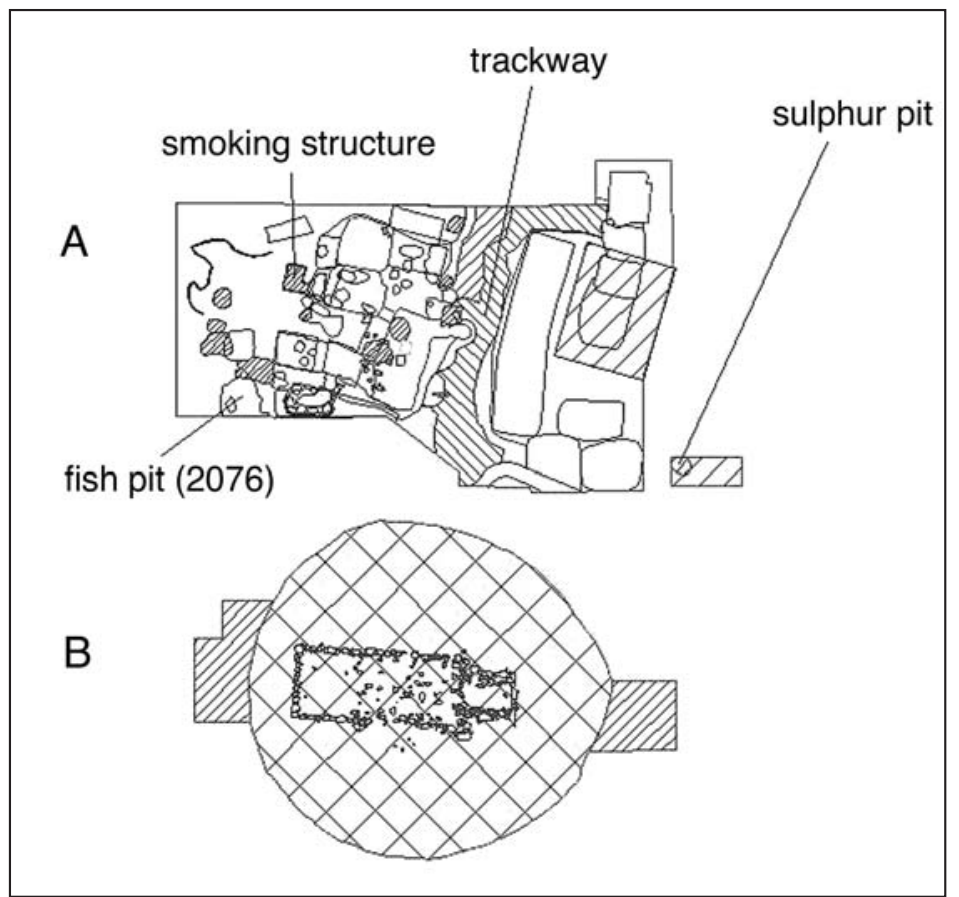


between them, clearly indicating that these were not year-round occupations. These casually constructed, often repaired, and frequently altered structures do not resemble contemporary Icelandic farmhouses or elite residences, and overall, their size and construction suggest purpose-specific occupation of the area during the summer market season. Other medieval Icelandic markets that share characteristics with the one at Gásir are Gautavík in east Iceland (Capelle 1982), and Maríuhöfn in southwest Iceland, as well as Kolkuós, the market site associated with the northern bishopric at Hólar (i.e., Kristjönudóttir 2005) in Skagafjörður, western neighbor to Eyjafjörður, where Gásir is situated (see Fig. 1).

Market area A (Figs. 2, 3) consists of multiple series of interlinked booth-like structures that align along a number of linked trackways. These structures exhibit a varied architecture with primarily large, deep-sunken buildings all slightly terraced into a gentle rise. These interior spaces were then subdivided and reinforced by irregular turf walls and linings, to form rooms of greatly varying shape and size. These subdivisions are presumed to reflect differing functions. A few of these rooms have rough stone floors; other occupation surfaces are formed from multiple fine layers of trampled soil and ash. A small number of rooms contain formal hearths or fire pits, while most possessed simple temporary hearths indicated by localized burning.

While only a small sample of the overall site has been excavated, and thus the complete extent of the market area is unknown, earthworks visible on the surface and through soil resistivity survey cover an area of c. $10,000 \mathrm{~m}^{2}$. In the recent excavations, c. $600 \mathrm{~m}^{2}$ of the market area has been examined, with only the upper portion of the total archaeological deposit excavated. In addition to the market area, the Gásir church and churchyard (area B in Fig. 3) overlooking the market area have been re-excavated (Vésteinsson, in Roberts et al. 2006). The church saw three building phases, with the last one after 1300. In this phase, the church was extended to a total length of $16 \mathrm{~m}$. Prevailing thought is that this imposing timber structure was built by the merchants at Gásir to express their religious beliefs, as a source and symbol of mercantile solidarity (perhaps not unlike the guild-chapels of contemporary urban Europe), but certainly also to impress the local Icelandic market participants, whose own parish churches were far more modest (Vésteinsson, in Roberts et al. 2006:18). No graves were found in the churchyard enclosure, despite full exposure and excellent conditions for bone preservation. The churchyard area may have occasionally served as a sanctified assembly area (and non-violent sanctuary space), but any foreign crew that died while residing at Gásir must have been buried elsewhere, possibly at one of the nearby parish churches, Glæsibær, Laugaland, or the monastic church at Möðruvellir.

\section{Trade Contacts}

Gásir can be viewed as a medieval seasonal proto-urban fair, more akin to the emporia of the Early Middle Ages than to most contemporary $14^{\text {th }}$-century commercial towns; its existence likely dependent upon authority providing market peace and regularizing the interactions between locals and visitors. The wealthy monastery of Möðruvellir located close to Gásir may have been economically involved with the activities of the market place; one $14^{\text {th }}$-century documentary account reports that the Möðruvellir monks accidentally burnt down their monastery after returning drunk from the Gásir market (Steingrimsson et al. 2003:367). In the early $14^{\text {th }}$ century, English fishermen-traders became very active in Icelandic waters, and began to face competition from German merchants of the Hanseatic League in the latter half of the $15^{\text {th }}$ century (Dorsteinsson 1970). Pottery remains recovered from the deposits at Gásir include Rhenish Siegburg stoneware, East Anglian green-glazed red-ware, and a single body shard of Spanish Majolica. All these pieces of pottery can be dated to about the $13^{\text {th }}-14^{\mathrm{h}}$ centuries AD, and except for the Majolica shard, which was very rare at that time, all types found at Gásir were in wide circulation in the medieval North Sea/North Atlantic region. Vessel forms include many beakers and jugs used for beer and wine consumption rather than food preparation. Two coarsely fired crucibles indicate on-site craft activity requiring high burning/ smelting temperatures (Mehler, in Roberts et al. 2004:61). Icelandic soils are not suitable for pottery production, and most Icelanders ate and drank from wooden or horn vessels, so that even these fairly simple and widely distributed medieval pottery forms could have carried an enhanced status-meaning and were likely used for celebratory occasions. The total Gásir pottery assemblage is quite impressive in diversity, and even more in numbers, for that of an Icelandic site from this period (see Gísladóttir, in Roberts et al. 2006:21).

In 2003, a count of all medieval ceramic fragments found in Iceland resulted in a total of ca. 30 vessels from the $13^{\text {th }}$ and $14^{\text {th }}$ centuries. At that point, with excavation activities still to be continued for another 3 years, 19 vessels had been recovered from Gásir, increasing the total number of Icelandic ceramics by more than $60 \%$ (Mehler, in Roberts et al. 2004:69). A total of 58 of baking plates made of imported schistose material were recovered from Gásir, comprising more than 50\% of the total Icelandic baking stone collection (Gísladóttir, in Roberts 2006a:22). 


\section{Bulk Goods and Luxury Exports}

The main bulk staple goods leaving Iceland after 1250 were dried cod fish (usually prepared as rounddried stockfish) and woolen cloth such as vaðmál (Karlsson 2000, Dorláksson 2008). At Gásir, some woolen cloth fragments were recovered, but as wool was the most common fabric worn by both Icelanders and continental Europeans in the Middle Ages, it is uncertain if these finds represent cloth intended for export (Gísladóttir, in Roberts et al. 2005). Since the analysis of the Gásir artifactual and environmental remains has not been finalized, detailed analysis of the recovered cloth might still inform on the nature of its purpose. The fish bones recovered that are still subject to further investigations appear to relate more directly to the provisioning of the site's occupants than to export, as will be discussed more extensively below. Less ambiguous is the find of a concentration of sulphur in what may be a processing pit, also presented in more detail below. Iceland and Sicily were the major medieval sources of sulphur, which was used as an insecticide, medicine, and increasingly for black powder manufacture as gunpowder weapons became more common on European battlefields in the $14^{\text {th }}-15^{\text {th }}$ centuries (Adderley et al. 2004b, Kramer 2001). The nearest extensive open deposits of volcanic sulphur are in the mountain ranges east of Lake Mývatn, some $100 \mathrm{~km}$ to the east, which were intermittently exploited for export in early modern times (Porsteinsson 1972). In addition to traditional bulk staple goods like dried fish and woolen cloth (Foote and Wilson 1970) or industrial sulphur, the Gásir site also was involved in the export of high status luxury goods. Gásir's archaeofauna yielded two gyrfalcon (Falco rusticolus) bones that were recovered from different contexts. While sea-eagles were regularly killed for stock protection and their feathers and bones do sporadically appear in Icelandic archaeofauna, falcons were not hunted, and their bones are extremely rare in collections (Harrison, in Roberts et al. 2004). These gyrfalcons were probably accidental deaths in transit in what we know from documentary sources to have been a well-known Icelandic export of birds associated with the highest (royal status) of the carefully ranked grades of high medieval falconry (Pórdarson 1957).

\section{Dating}

The chronology of the whole Gásir site has been assessed through radiocarbon, tephrochronology, artifacts, and documentary evidence. The earliest mention of Gásir's involvement in market activities in AD 1163 is found in the Prestssaga Guðmundar góða (Jóhannesson et al. 1946:119), while the last time written sources mention the seasonal fair is AD 1391 (Storm 1888:367). The site has yielded
$\mathrm{C}^{14}$ results (Cook 2006) that place it from the $13^{\text {th }}$ century AD through to the early $15^{\text {th }}$, which loosely corresponds with documentary sources. Few of the artifacts are diagnostic for high-resolution dating, with the pottery assemblage broadly datable to the $13^{\text {th }}-14^{\text {th }}$ centuries (Mehler, in Roberts et al. 2002b: 46). Tephrochronological dating further refines this chronology; all excavated layers are stratigraphically later than the Grimsvötn volcanic tephra horizon dated circa AD 1300 (Magnus Sigurgeirsson, in Roberts et al. 2002b). Further unexcavated layers clearly continue to some depth below the limits of excavation, which have intentionally focused upon the later phases. Whilst Gásir may have origins as early as the Viking period, to date there is no unequivocal evidence to support this assumption, and this paper deals with the fairly narrow time range between the circa 1300 tephra fall and the end of the market around 1400 .

Radiocarbon dates and associated carbon and nitrogen isotopic assays carried out on mammal bone and marine shell at the Scottish Universities Reactor Center (SUERC) by Gordon Cook and Philippa Ascough are presented in Table 1 (discussion in Ascough et al. 2005, 2006). As expected, the marine shellfish and the seal bone show much higher delta C13 values (values above -15 to $-16 \%$ indicate marine food-web participation) than those of the cows (terrestrial food web), and these samples generate radiocarbon dates far too old for the medieval site. The very low N15 values of two of the cattle bone samples (SUERC 8634, 8635) are similar to the values produced from nearby Mývatn area sites with highland low-arctic pastures, while the higher N15 value (SUERC 8629) suggests habitual grazing on richer lowland vegetation (see Cook, in McGovern et al. 2007). While more isotopic assays are now underway, these diverse delta N15 values from apparently contemporary cattle bone samples already may suggest that Gásir drew upon a wide catchment area for the cattle that provisioned its market.

\section{Methods and Materials}

Excavation at Gásir was conducted according to standard methodologies described in the Field

Table 1. Results from isotopic studies on faunal remains from context (528) (calibration according to Bronk 2003).

\begin{tabular}{llcrrr}
$\begin{array}{l}\text { SUERC } \\
\#\end{array}$ & Material & $\begin{array}{c}\text { Radiocarbon } \\
\text { years BP }\end{array}$ & $\begin{array}{c}\text { delta } \\
\text { sd }\end{array}$ & $\begin{array}{r}\text { delta } \\
\text { C13 }\end{array}$ & N15 \\
\hline 8635 & Cattle bone & 795 & 35 & -22.5 & 2.8 \\
8634 & Cattle bone & 595 & 35 & -22.1 & 2.2 \\
8629 & Cattle bone & 645 & 40 & -21.8 & 7.3 \\
8633 & Seal bone & 1145 & 35 & -12.7 & 14.4 \\
8638 & Clam shell & 1165 & 35 & 0.5 & \\
8639 & Clam shell & 1305 & 35 & 1.9 & \\
8637 & Clam shell & 1175 & 35 & 2.5 & \\
8636 & Clam shell & 1200 & 35 & 2.8 & \\
\hline
\end{tabular}


Manual of FSí (http://www.fornleif.is/utgafa/ handbok)_an adapted version of the Single Context Planning methodology of the Museum of London (Museum of London 1994). Excavation was supplemented with sampling for flotation, geo-chemistry, and micromorphology following North Atlantic Biocultural Organization (NABO) recommendations, to support the study of plant remains, industrial activities, and other aspects of the site formation process. Dry-sieving through 4-mm mesh was applied to all midden contexts. Site contexts 2076 and 520, where, respectively, extensive fish remains and sulphur materials were found, were subject to targeted wholesoil sampling for post-excavation analysis.

The faunal materials were processed at the City University of New York (CUNY) Northern Science and Education Center (NORSEC) laboratories in New York City and Brooklyn, NY, USA. Recording and data curation followed the NABONE protocols followed for other archaeofauna from Iceland, Faroes, Greenland, and northern Norway (NABO Zooarchaeological Working Group 2004; see www.nabohome.org for downloadable version 8). Following widespread North Atlantic tradition, bone-fragment quantification makes use of the Number of Identified Specimens (NISP) method (Grayson 1984). Mammal measurements follow von den Driesch (1976), fish metrics follow Wheeler and Jones (1989), fish identifications follow FISHBONE 3.1 (2003; also at www.nabohome.org), and sheep/goat distinctions follow Boessneck (1969) and Mainland and Halstead (2005). Tooth-wear stage studies follow Grant (1982) and long-bone fusion stage calibrations follow Reitz and Wing (1999), with overall presentation of age reconstruction following Enghoff (2003).

Sulphur materials were sampled from context 520 on the site, positioned away from the market area (Fig. 4). The samples were prepared for analysis by impregnation with polyester resin. Optical micromorphology (thin sections under microscope) method was applied for examination of the sedimentary context of the undisturbed in situ sulphur materials. All the samples, including the modern Icleandic ones and the ones from Gásir and the Darsser Kogge, underwent micro-scale $\mathrm{X}$-ray flourescense to establish their elemenatal composition (Adderley et al. 2004a). Their mineralogy was established by micro-scale X-ray diffraction using established thin-section analysis methods (Adderley et al. 2004a, Kennedy et al. 2004) on the microfocused X-ray beamline at the ESRF synchrotron.

\section{Structures and Their Function}

The main site area consists of two clusters (East and West) of densely interlinked buildings that are divided by street-like trackways. While there is no good proof to date that this division constitutes formally maintained movement corridors, it does seem to provide a fundamental principle for settlement layout. The function of the structures at Gásir is often hard to evaluate, due to the multiple phases of occupation and re-use and re-excavation of the semi-subterranean booth structures. It is likely that these fairly casually constructed buildings may in fact have shifted function repeatedly, and if contemporary medieval urban contexts are any guide, there may have been extensive overlap between what today would be considered public, private, commercial, and working spaces (Hall and Hunter-Mann 2004). However, some of the facilities can be determined to have specific usages, such as a "smoking room," a room $2.4 \mathrm{~m}$ long x 1.4m wide x 1.2m deep, the floor area of which consists largely of a hearth filled with charred horse dung (see Fig. 3; Roberts et al. 2006:12). In 2005, a 10- x 5-m extension of the western part of area A resulted in the recovery of a substantial midden deposit (context 2076) filling a pit, or sunken feature. The fish midden deposit contains predominantly cod and haddock elements, with cranial bone elements dwarfing the number of post cranial elements, suggesting a specialized deposit resulting from on-site fish cutting (see

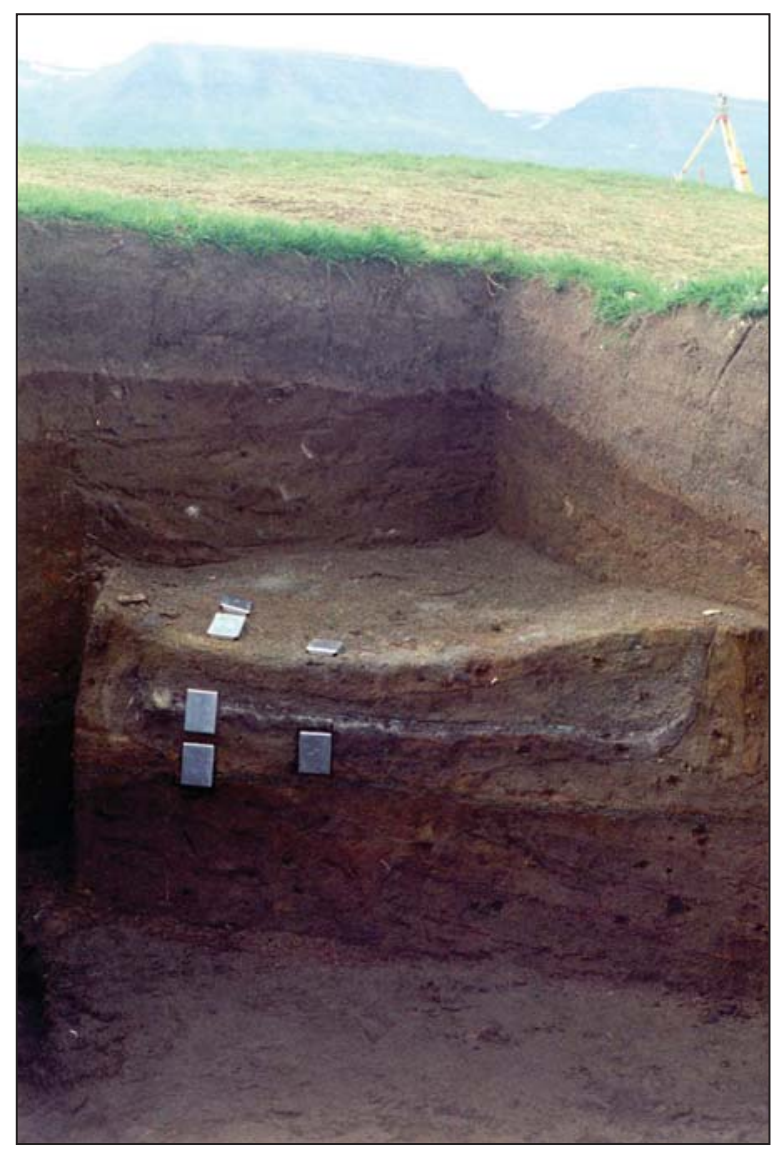

Figure 4. Sampling locations in the sulfur-rich pit feature at Gásir (520). Photograph (c) W.P. Adderley. 
Perdikaris and McGovern 2008). Less-specialized facilities such as dwelling or meeting spaces can be also identified, but further interpretation of many of these complex structures is still underway (Roberts et al. 2006). There clearly seem to be gradations in the quality of probable dwellings, with some structures well provided with paved floors and formally constructed hearths, and others far more basic.

This combination of multiple functionally (and perhaps socially) differentiated semi-subterranean structures arranged around a set of common open spaces and what seems to be linear movement corridors is a layout also known from other trading sites such as Gautavík and Maríuhöfn (Capelle 1982 and Dorkelsson 2004), but quite different from what we know of other Icelandic settlement types. Icelandic farmsteads underwent multiple changes in layout through time, beginning with a mix of semi-subterranean pit houses (sunken featured structures somewhat different from the Gásir booths) and timber and turf halls with separate animal byres and hay barns, and evolving by medieval times into a centralized turf and stone-built complex of human and animal buildings arranged around a set of interior passages, with pit houses largely disappearing by the late 11th century (see Vésteinsson 2004 for review). While large farmsteads often had partly paved pathways within the farmyard area, the major spatial divisions were the concentric nested circles of farmyard, homefield, and outfield. These are attested in legal as well as literary accounts, and clearly formed key elements in organization of a cultural landscape (Hastrup 1985). Other settlement types included upland shielings (sel), which often converted back and forth between seasonally occupied summer herding centers and small year-round farms, depending on climate and economy. The sel tended to resemble normal lowland farms with additional stock housing and animal-management structures (pens, folds, milking enclosures; Pálsdóttir 2005). Clusters of small structures superficially similar individually to the Gásir buildings are found in many coastal areas, but these are specialized fishing stations occupied seasonally during the winter fishing, with their location closely tied to access to offshore fishing grounds (Edvardsson et al. 2004). The oldest radiocarbon dated fishing station is at Akurvík in Strandasysla in the West Fjords, which has produced basal dates in the mid-13th century and terminal dates in the mid-15th century for a series of stratified occupations of a shell sand beach (Amundsen et al. 2005). The Akurvík site has not been fully excavated, but investigations of a long erosion cut profile allowed the documentation of several early "fishing booth" structures dating to both early and late phases. While both sites were characterized by seasonal occupation of structures not associated with farming, there is little structural similarity between the medieval fishing booths and the Gásir sunken featured buildings.

The negative feature with context number 520, producing the Gásir in situ sulphur samples (Fig. 4) just outside Area A (Fig. 3), was determined to likely be a sulphur-processing pit (Adderley et al. 2004b:60). The Gásir archaeological in situ sulphur samples were compared with modern raw sulphur materials collected from known Icelandic sites that were historically involved with sulphur mining. An additional sample of archaeological sulphur was taken from the Hanseatic trading ship called Darsser Kogge, whose date, established through dendrochronolgical analysis, was set at 1277-1293 AD (Adderley et al. 2004b:60). The results from the field examination and micromorphological analysis of the in situ Gásir sulphur samples indicated that the materials processed at the trading site are similar to modern samples from traditional Icelandic sulphur sources. This finding can be viewed as an indicator for Gásir's involvement in the Icelandic sulphur trade. These volcanic materials were sought-after in the "pan-European" sulphur exchange (Adderley et al. 2004b:61, Kutney 2007).

\section{Zooarchaeological Evidence}

The Gásir faunal remains have been continuously analyzed throughout the excavation period, and the total bone count by taxon (number of identified species [NISP]) is presented in Table 2, combining all contexts within the $14^{\text {th }}$ century phase of the site. Where further taxonomic division was impossible, fragments were lumped into "large terrestrial mammal" (cattle-horse sized), "medium terrestrial mammal" (sheep-pig sized) and "small terrestrial mammal" (fox-small dog sized) categories.

The Gásir archaeofauna thus has a total NISP of 8647 out of a total number of fragments (TNF) of 17,625 . As is common on Icelandic medieval sites, the majority of the identified bone fragments are from fish, which are mainly marine fish of the cod family (Gadidae), although a few halibut and flatfish bones have been recovered as well as a few freshwater fish bones. Domestic mammals are represented by the full range of species known from Iceland, including pigs, horses, dogs, and goats as well as the more common cattle and sheep. Wild mammals identified are mainly seals and whales, though as whale bones were extensively used for craftwork and construction in the North Atlantic region, it need not reflect a contribution to diet (Szabo 2005). Bird bones are mainly eider duck and 
guillemot or murre, both still common locally, while the two gyrfalcon bones noted above provide a

Table 2. Aggregated bone fragment count.

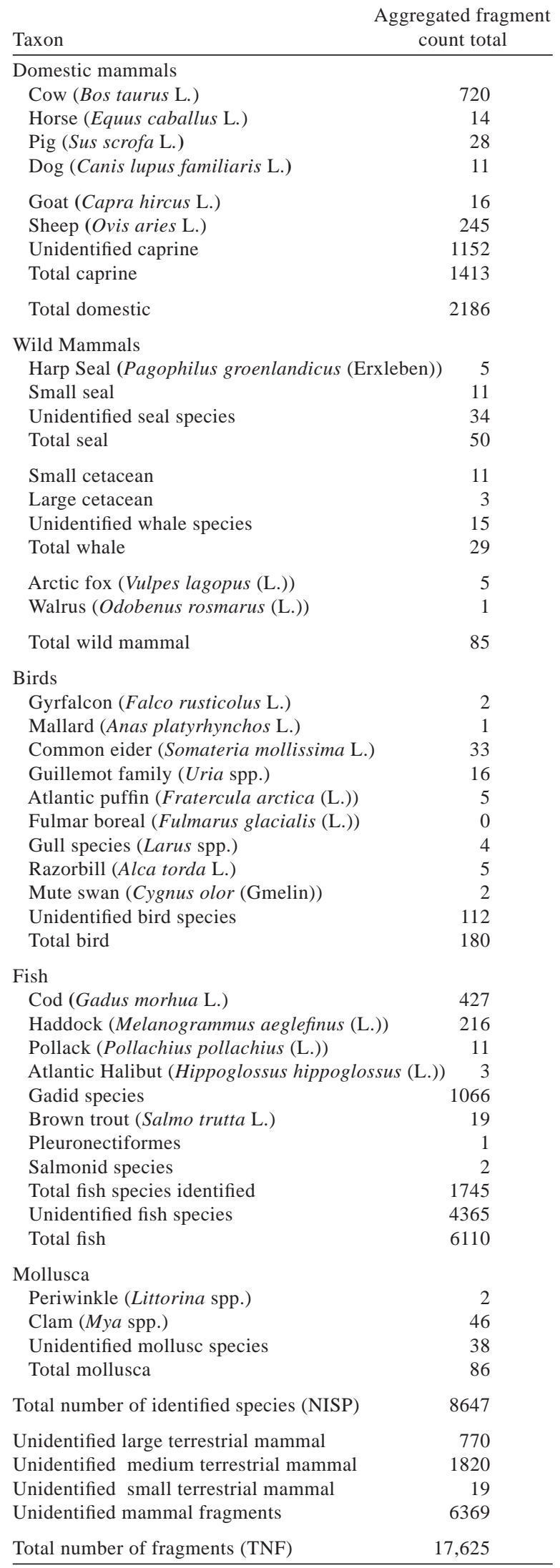

unique reminder of literary and legal descriptions of Iceland as a source for this royal falconry bird in the Middle Ages. Equally exotic is the presence of walrus ivory and harp seal bones, both today associated with arctic drift ice and now uncommon visitors to Icelandic waters.

Figure 5 presents a comparison of major animal taxa per site of selected later medieval Icelandic collections. Bessastaðir lies just south of Reykjavík and was a high-status farm and seat of the Danish Governor during the Late Middle Ages (Amorosi 1996; Amorosi et al. 1992; Ólafsson 1991a, b; McGovern 1990). Víðey was a rich monastic site outside modern Reykjavík harbor (Amorosi 1996), Svalbarð is a long occupied local church farm in the north east (Amorosi 1996, Amorosi et al. 1992), and as noted, Akurvík is a seasonally occupied fishing station in the West fjords of Iceland with two major phases (Akurvík 24, Akurvík 22) dated to the $13^{\text {th }}$ and $15^{\text {th }}$ centuries, respectively (Amundsen et al. 2005, Krivogorskaya et al. 2005). The overall Gásir archaeofauna does not fit exactly with the high-status farm archaeofauna profile such as that from Víðey or Svalbarð, despite displaying a broadly similar mix of fish and domestic stock, lacking the substantial amounts of bird and sea-mammal remains found on the monastery or local elite farm. Gásir's archaeofauna also contrasts with that of the elite manor at Bessastaðir, with its strong concentration upon domestic stock, and with both phases of the cod-dominated Akurvík fishing station.

\section{Comparing Medieval Archaeofauna: Domestic Mammals}

The domestic mammal proportions (Fig. 6) at Gásir most closely resemble the high-status manor at Bessastaðir and the rich monastic center on Víðey in the abundance of cattle bones, and contrast with the reasonably wealthy but far northeastern church farm of Svalbarð, and with the small Mývatn farm of Steinbogi (Amorosi et al.1992, McGovern 1990). At Gásir, the ratio of 1.97 caprine bones for every cattle bone contrasts with a caprine-to-cattle ratio of close to twenty to one for most rural sites in northern Iceland after ca. AD 1250 (Vésteinsson and McGovern, in prep.). Had Gásir been an Icelandic farm site of the Late Middle Ages, its overall domestic mammal proportions would strongly suggest high status and prosperous farming conditions.

\section{Cattle and Sheep Consumption Patterns at Gásir}

The reconstructed age structure of the cattle and sheep bones discarded at Gásir expands upon this impression of status, while confirming that Gásir was certainly not functioning as a farm. North Atlantic 


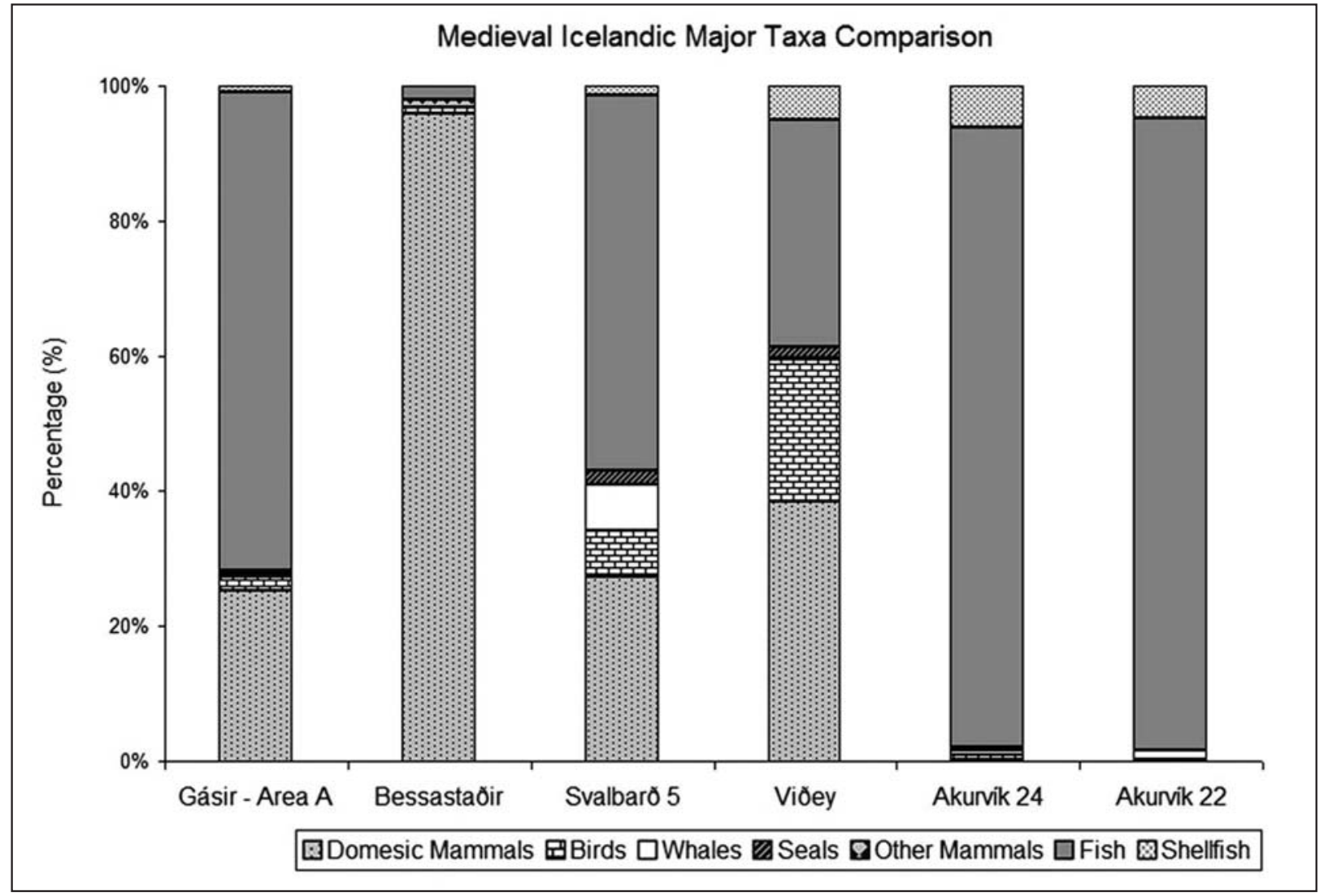

Figure 5. Comparison of overall relative abundance of major species groups at later medieval Icelandic sites. Sources: Svalbarð 5 (Amorosi 1996); Víðey (Amorosi 1996); Bessastaðir (Amorosi 1996; Amorosi et al. 1992; McGovern 1990; Ólafsson 1991a, b), and Steinbogi (Brewington et al. 2004).

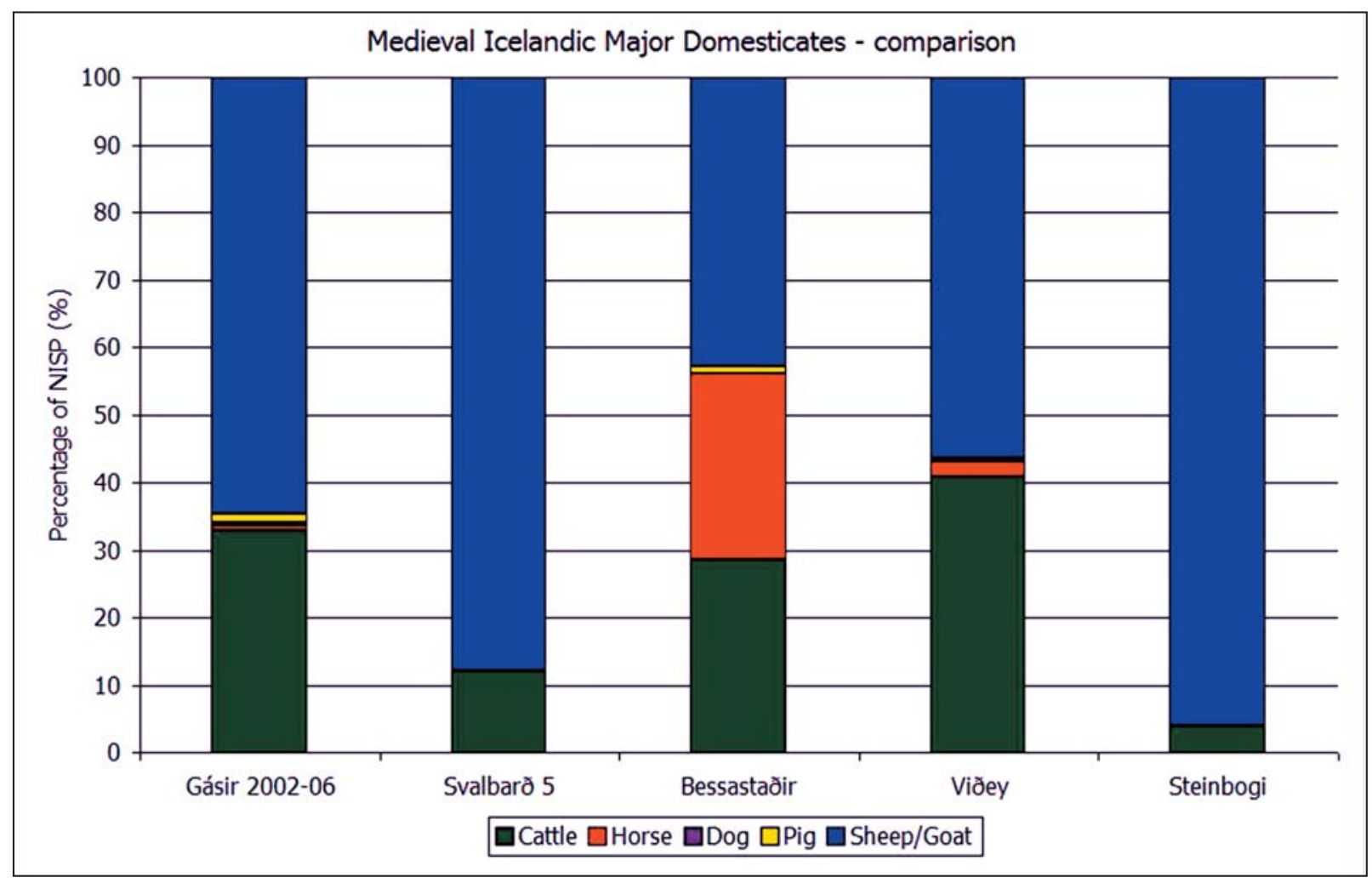

Figure 6. Domestic mammal proportions from selected Icelandic sites. Sources: Svalbarð 5 (Amorosi 1996); Víðey (Amorosi 1996); Bessastaðir (Amorosi 1996; Amorosi et al. 1992; McGovern 1990; Ólafsson 1991a, b), and Steinbogi (Brewington et al. 2004). 
archaeofauna of all periods tend to produce a pattern of reconstructed cattle age at death with many very young (neonatal) bones from animals much less than a year old culled to reserve milk for human consumption. These high percentages of neonatal cattle bones have been convincingly tied to a strongly focused dairy production strategy in a context of limited grazing, and are usually interpreted as reflecting the Norse farmer's understandable determination to extract the maximum amount of storable dairy produce from the cows available (Halstead 1998, Mulville et al. 2005, Reichstein 2002). Figure 7 illustrates the relative percentage of neonatal calf bone remains compared to several Viking Age and Late Medieval Icelandic sites. The marked shortage of neonatal cattle bones at Gásir is evident, suggesting that dairy production of the normal Icelandic type was not taking place on site.

If the Gásir residents were not consuming many young calves, they were also not eating very many old, worn out milk cattle, which would represent the other source of beef normally consumed by Icelandic dairy farmers. Analysis of eruption and wear of cattle tooth rows as well as long-bone fusion comparison studies (Grant 1982, Reitz and Wing 1999) produce an average age of death for the adult cattle consumed at Gásir between 1.01.5 years and 2.5-3.0 years, suggesting culling of well-grown but not fully mature juvenile cattle as well as young adult individuals (Harrison 2006).

The cattle long-bone fusion proportions (Fig. 8) indicate that at late medieval Gásir, most of the young cattle survived the stage of distal epiphysis fusion of the humerus, which occurs at around 1-1.5 years of age. There would appear to be considerable cattle mortality between $1-1.5$ years and 2.5-3 yrs at Gásir, again suggesting kill off of large but not fully mature juvenile cattle as well as the presence of adults (note the different fall-off of survivorship at Hofstaðir and Sveigakot; Harrison 2006). This culling profile is a near-perfect match for a hypothetical "prime beef" profile, and cannot represent the provisioning of the residents of Gásir by the natural off-take of very old or very young cattle produced as a by-product of a dairying economy. The beef animals being fed just to the top of their growth curve would constitute quite expensive parts of the farming strategy: rather than killing them early on before they needed to be fed

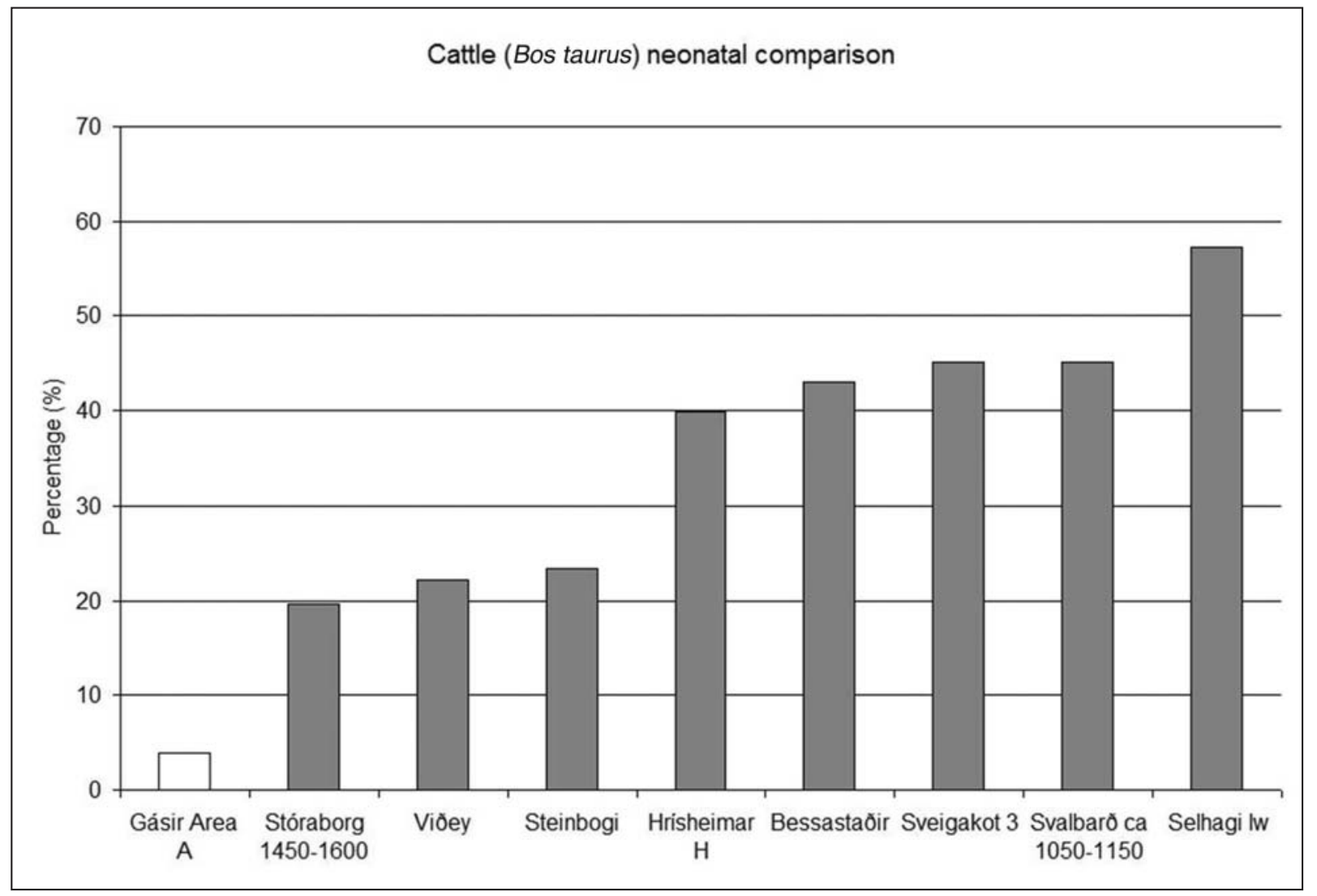

Figure 7. Late Medieval Gásir neonatal cattle percentages (white bar) compared to earlier Medieval medium status farmsteads in 1) Sveigakot: (McGovern et al. 2004), Hrísheimar (McGovern and Perdikaris 2002), Selhagi (McGovern and Perdikaris 2007 [Draft]), and Steinbogi (Brewington et al. 2004), and 2) Mývatnssveit: the Late Medieval church farm at Svalbarð in northeastern Iceland (Amorosi 1996:397), the Late Medieval monastic center at Viðey in Reykjavík (Amorosi 1996:403), the the Late Medieval middle- to high-status farm at Stóraborg in the Southwest (Amorosi 1996:373), and the Late Medieval period of the high-status mansion at Bessastaðir (Amorosi 1996:335) close to Reykjavík. 
through the winter with extra hay (see Vésteinsson et al. 2003:11), the beef cows were fed through at least one if not two winters. It is possible that some of the pasturelands in the area (i.e., in the holdings of Möðruvellir monastery) may have been exclusively used for the feeding of beef cattle. Similar herding practices may have been existent on the pasturelands owned by the wealthy Munkapverárklaustur just south of Eyjafjord; in 1515, the Benedictine monastery supposedly held 18 cows, 3 calves, and 22 young bulls (naut) that were used for meat (Doroddsen 1919, 223).

The age structure of the caprines (nearly all sheep) at Gásir also raises some questions about provisioning. Icelandic sheep were regularly managed for multiple products (milk, wool, meat, tallow), and most farmers maintained both younger fertile ewes for milk and older infertile ewes and old castrate wethers for wool production (Aðalsteinsson 1991). At Gásir, there is again a somewhat atypical pattern of mortality. Caprine long-bone fusion data suggests that most of the Gásir sheep were killed between 3.5 and 4.5 years of age-apparently a cull of animals in the prime meat range, and not the agriculturally cheaper option of the worn-out milking ewes or tough, old wethers who fed Icelandic farm families. The caprine dental eruption pattern indicates that almost $60 \%$ of the caprines died with full adult dentition in wear and another 20\% were culled near their adult size at the end of their second summer. Thus, nearly all of the analyzed caprine mandibles recovered from Gásir show eruption patterns of adult or nearly full-grown juveniles, with very few younger animals present. Tooth wear patterns on adult mandibles are only indirectly tied to age at death, and differential grazing patterns can strongly affect rates of tooth wear (Grant 1982, Mainland 2006, Mainland and Halstead 2005), but it is clear from the Gásir sheep mandibles that few show the extreme tooth wear characteristic of old ewes or wethers (Harrison 2006). Tooth wear patterns on the last erupting third molar (M3; Fig. 9) suggest that most of the adult sheep consumed at Gásir were young to middle-aged adults rather than the old ewes or wethers that normally show very heavily worn M3 surfaces and often exhibit severe periodontal disease associated with grit and soil ingestion in north Iceland. Our various sources for reconstructing age at death for both cattle and sheep thus suggest similar patterns of consumption of animals as nearly mature or young adults - prime cuts seldom consumed by most medieval Icelanders.

A number of pig (Sus scrofa) bones are among the Gásir faunal collection, making up just over one percent of identified domestic mammals. This find is very atypical of Late Medieval Icelandic sites, where

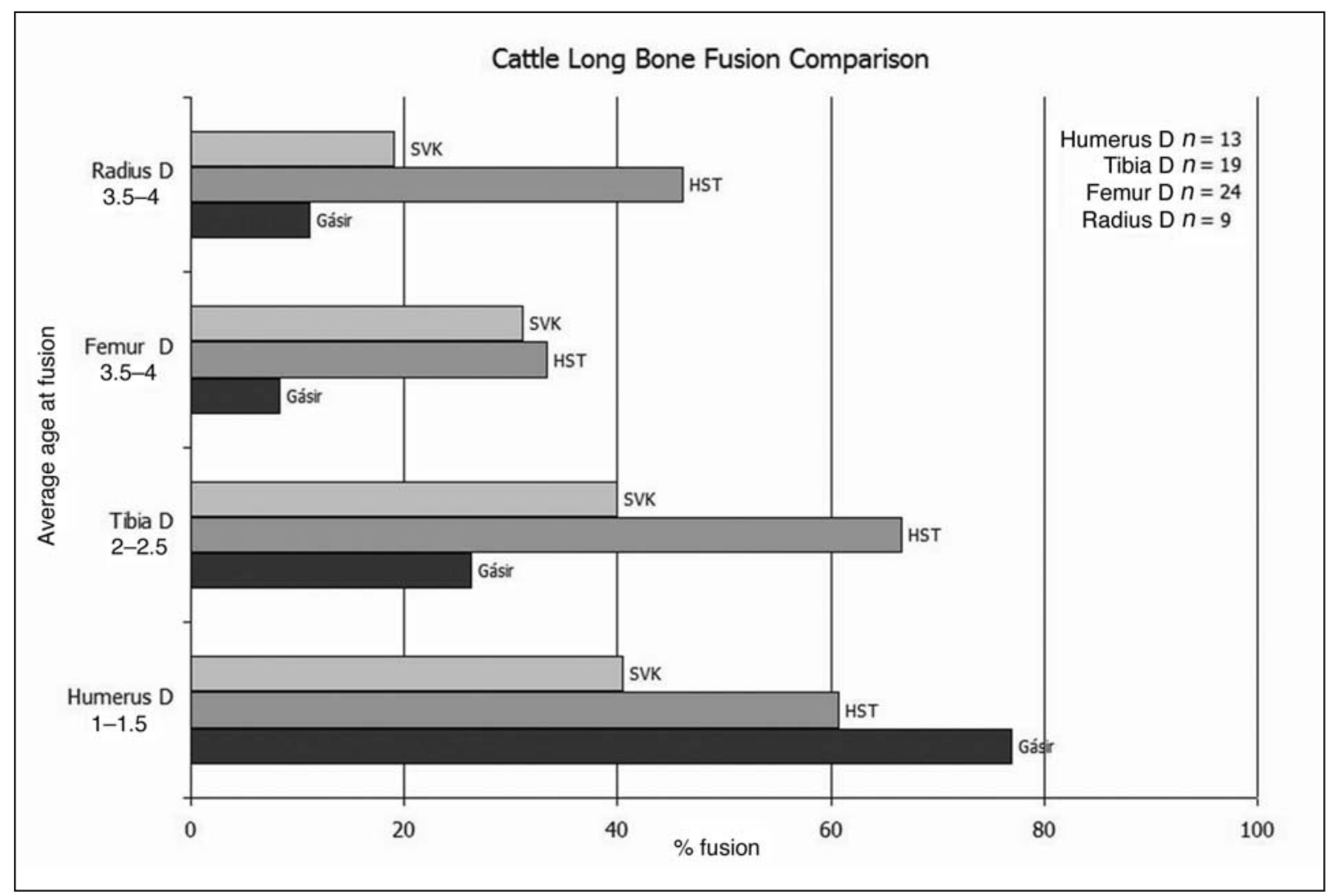

Figure 8. Cattle long-bone fusion comparison. The abbreviations stand for the Viking age sites at Sveigakot (SVK) and Hofstaðir (HST). 
pig bones are usually totally absent. While pigs were part of the original introduced domestic fauna and some survived to the $17^{\text {th }}$ century in a few favored areas, by the $14^{\text {th }}$ century, the pigs had become very rare, especially in northern Iceland (McGovern and Perdikaris 2002; see also Arge et al. 2008). Most Gásir pig bones are long bones, and most have heavy chopping marks suggesting dismemberment with a heavy cleaver (especially femur [75\%] and humerus [80\%]). These marks could mean that some pig bones reached Gásir in hams or salt pork rather than in live animals (Perdikaris et al. 2002, Wigh 2001). However, some skeletal element combinations suggest butchery of a live pig on site rather than consumption of preserved meat (for butchery discussion, see Prilloff 2000). Live pigs were regularly transported aboard ships in the medieval and early modern periods to provide a convenient source of fresh meat. Robinson and Aaby (1994) report pig dung recovered among animal bedding material in the late $13^{\text {th }}$ century Gedesby shipwreck from Denmark. John Cabot's ship the Matthew was stocked in Bristol with both live chickens and pigs for its 1497 voyage to Newfoundland (Morison 1971, Munn 1936). It is therefore quite possible that earlier $14^{\text {th }}$-century vessels calling in Iceland were similarly provisioned. Icelanders may have been able to encounter exotic pork at tables in Gásir, but one cannot exclude the possibility that there were still pigs raised in the Gásir neighborhood in the $14^{\text {th }}$ Century.
While dog tooth marks on the bones of other species are very widespread in Icelandic archaeofauna, dog bones are not common in domestic refuse deposits. In pre-Christian times, dogs were often included in human burials, and the size and general configuration of these Viking Age dogs closely matches the modern Icelandic breed (Friðriksson and Eldjárn 2006, McGovern et al. 2007). As dogs were not normally eaten in medieval Scandinavia, it is unusual to find more than one or two bones outside burial contexts, and the exceptional finds of multiple dog bones (some with cut marks) on terminal floor layers in the Western Settlement of Norse Greenland have been taken as indications of a terminal provisioning crisis closely associated with abandonment (McGovern et al. 1996). The only other Icelandic exception is the early modern archaeofauna from rapidly urbanizing $17^{\text {th }}-19^{\text {th }}$-century Reykjavik at Tjarnargata 3c, where dog bones as well as rats and mice were mixed into a streetmidden deposit that seems to have attracted feral commensual animals of several species (Perdikaris et al. 2002). The presence of a total of 11 scattered dog bones at Gásir may again reflect a seasonally urban-like social environment in which management and control of dogs may have been different from normal farmstead contexts. O'Connor (in Thomas 2005:97) notes that deposition of pet carcasses in midden dumps is not necessarily revealing about their treatment in life and also notes the increased

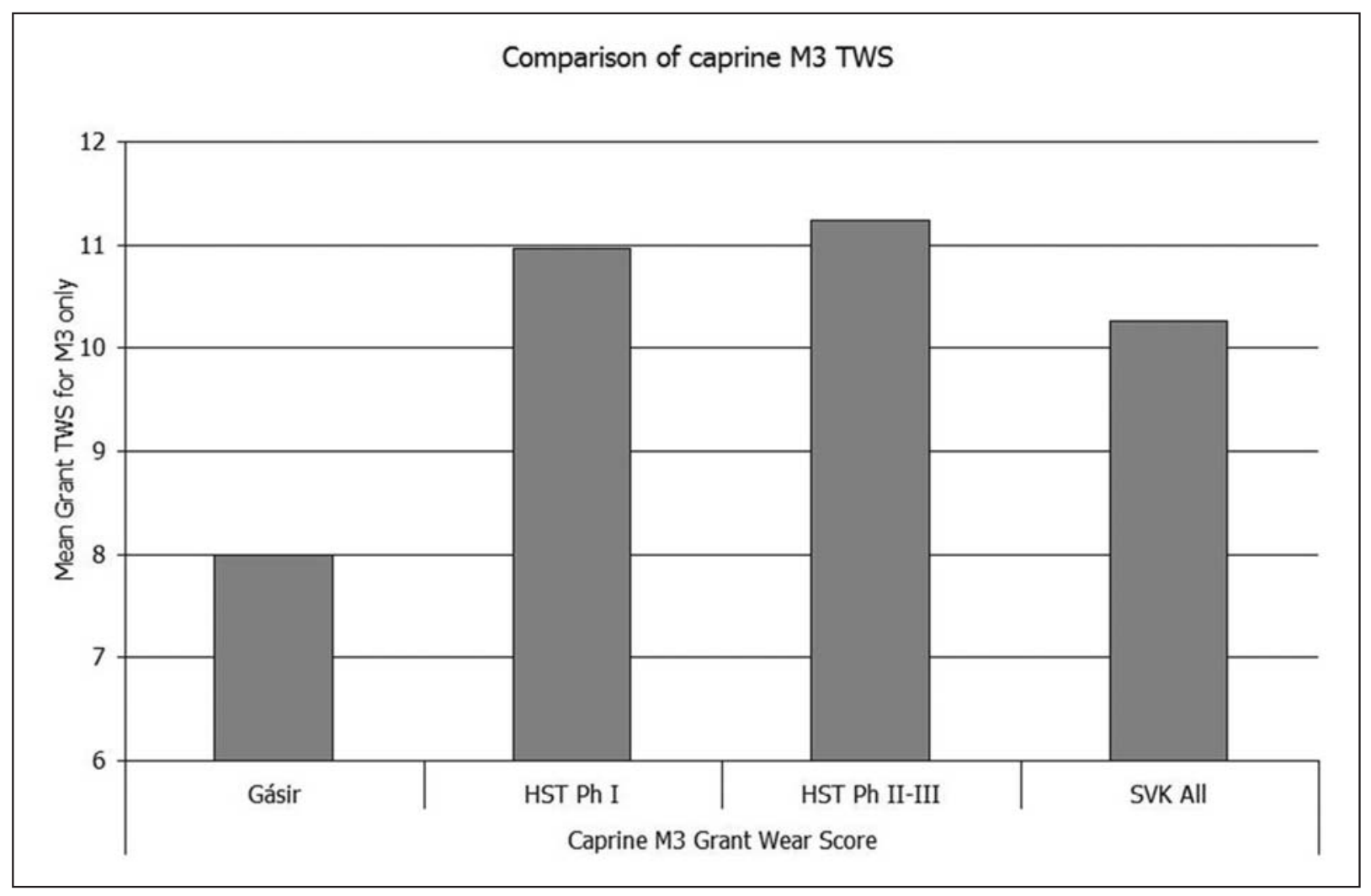

Figure 9. Caprine M3 tooth qear stages. 
prevalence of dog bones in urban vs. rural sites in medieval Britain.

However, some of the dogs bones present in the Gásir faunal remains suggest still more exotic human-canine interactions. At least three very small lap dogs may have died on the site leaving both long bone and skull fragments behind. Table 3 presents the stature reconstruction for these small animals using the formulae of von den Driesch and Boessneck (1974) and Harcourt (1974). Both methods provide shoulder height estimates between 26 and $33 \mathrm{~cm}$. Icelandic sheep dogs (probably imported at first settlement and the only current native breed) have a shoulder height of $45-47 \mathrm{~cm}$ for males and 40-42 cm for females (FCI Breed-Standard No. 289/29.11.2000/GB; www.icelanddog.org), and have a very different cranial morphology (Fig. 10) from the skull of a small-sized dog.

Such small "lap” dogs were status items in High Medieval Europe (Prilloff 2000) and have been found in other Late Medieval Icelandic archaeofauna, in monastic contexts (Pálsdóttir 2005b) and at the medieval trading station at Kolkuós which was connected to the northern bishop's see at Hólar (R. Traustadóttir, Hólar University College, North Iceland, pers. comm. 2004). Visiting traders (and

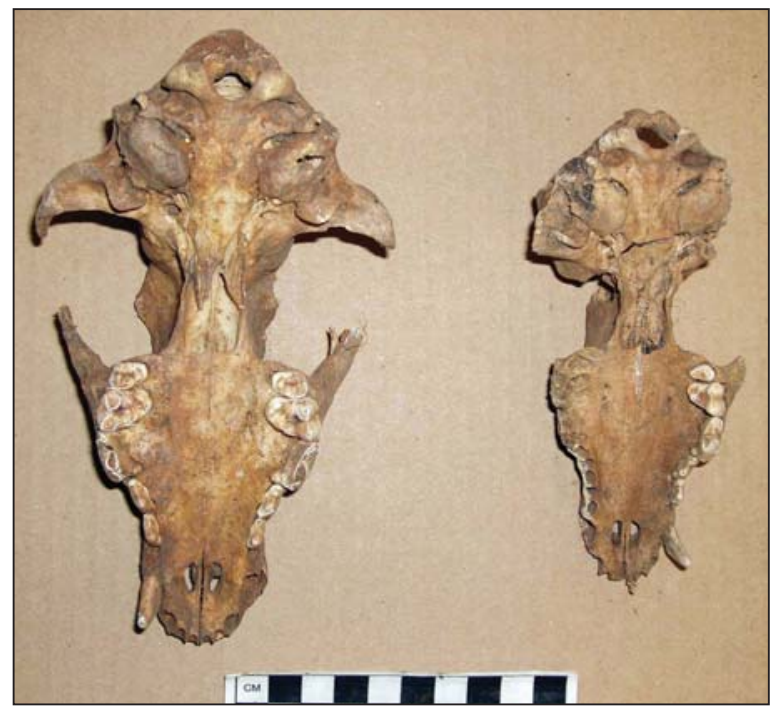

Figure 10. Medium-sized Icelandic dog (Skálholt, modern deposit) versus specimen of small size from medieval Gásir, context 2812 (crania, inferior position). Scale in $\mathrm{cm}$. perhaps a few Icelandic aristocrats) made fashion statements with these imported lap dogs, but apparently they never replaced the larger, more utilitarian sheep-herding breed of the Viking age.

\section{Wild Mammals}

A handful of Arctic fox (Alopex lagopus) bones recovered from various deposits did not offer conclusive evidence if these individuals were used in fur production or trading or if they were simply killed for being an annoyance as scavengers (Hersteinsson 1989). There is some evidence for skinning of foxes at the $9^{\text {th }}$-late $12^{\text {th }}$-century site of Sveigakot (McGovern et al. 2004).

As the Gásir site is located so close to the ocean, marine mammal fragments found among the archaeofauna were no great surprise. Whale bone fragments at Gásir fall into two overlapping categories: those showing signs of working as raw material for artifacts (mainly coming from great whales), and those suggesting whale meat provisioning, with the latter coming from animals in the small whale/porpoise size range. Late medieval cookbooks include many recipes for young porpoise to be served as high-status dishes, but porpoise and small whales have been consumed in many parts of the North Atlantic since prehistory (Szabo 2005). Bond and O’Connor (1999: 418) note that whale and seal meat was sometimes classed with fish in medieval times as suitable for consumption on meatless fast days, though practice varied through time and location (Adamson 2004:44; see also discussion in Müldner and Richards 2007).

The seal bones found at Gásir include both adults and newborn young, and butchery marks suggest that they were eaten, although seal skins were also a widespread North Atlantic export. While seals were regularly eaten by coastal people, in later medieval cookbooks, seals were considered as "sailors' food" (Adamson 2004). The seal bones at Gásir thus may be an indicator for the presence of seafaring people at the trading station or simply a reflection of normal Icelandic dietary preferences. The seal bones that could be speciated were found to be from the ice-riding harp seal (Phoca groenlandica) rather than the local harbor seals (P. vitulina) still common in Eyjafjörður

Table 3. Reconstruction of the shoulder height in the small dog (Canis familiaris) specimens found at Gásir. Two reconstruction factors were used and resulted in quite similar shoulder heights.

\begin{tabular}{|c|c|c|c|c|c|c|}
\hline Context & $\begin{array}{l}\text { Skeletal } \\
\text { element } \\
\text { (bone) }\end{array}$ & $\begin{array}{l}\text { Greatest } \\
\text { length (GL) } \\
\text { of bone }\end{array}$ & $\begin{array}{c}\text { Size- } \\
\text { reconstruction } \\
\text { factor }^{\mathrm{A}}\end{array}$ & $\begin{array}{c}\text { Reconstructed } \\
\text { shoulder } \\
\text { height }\end{array}$ & $\begin{array}{l}\text { Size- } \\
\text { reconstruction } \\
\text { measurement }^{\mathrm{B}}\end{array}$ & $\begin{array}{c}\text { Reconstructed } \\
\text { shoulder } \\
\text { height }\end{array}$ \\
\hline 1551 & Tibia & $90.00 \mathrm{~mm}$ & 2.92 & $26.3 \mathrm{~cm}$ & $(2.92 x t l)+9.41$ & $27.2 \mathrm{~cm}$ \\
\hline 2812 & Humerus & $98.00 \mathrm{~mm}$ & 3.37 & $33.0 \mathrm{~cm}$ & $(3.43 x t l)-26.54$ & $31.0 \mathrm{~cm}$ \\
\hline 2851 & Humerus & $98.55 \mathrm{~mm}$ & 3.37 & $33.2 \mathrm{~cm}$ & $(3.43 x t l)-26.54$ & $31.2 \mathrm{~cm}$ \\
\hline
\end{tabular}


today. Harp seals are common in Icelandic waters only during periods of heavy drift ice and have been associated with later medieval climatic conditions in the North Atlantic, particularly the heavy summer sea ice encountered in Denmark Strait after 1300 (Amorosi et al. 1992; Ogilvie 1991; Ogilvie et al., in prep.; Woollett 2004). In addition to the seal and whale bone fragments, a single piece of walrus (Odobenus rosmarus) tusk was recovered from Gásir (Fig. 11). This fragment is the proximal end of a tusk, right at the apex of the deep tooth root, and has been cut off with a medieval narrow-bladed backed saw. While the whole walrus tusks dating to circa 900 A.D. (before the settlement of Greenland) recovered from the very early long hall at Aðalstræti in Reykjavik probably came from local Icelandic walrus populations (Tinsley and McGovern 2002, Vésteinsson 2006), these local populations were certainly extinct by the later Middle Ages. Walrus were heavily exploited by the Norse Greenlanders (Pálsdóttir 2006), and the frequency of the dense maxillary bone fragments and occasional chips of tusk ivory in midden and floor deposits suggests widespread community involvement in the walrus hunt and the final extraction of the tusk ivory on the home farms (Dugmore et al. 2007, McGovern et al. 1996).

This sawn tusk root (Fig. 11) is unlike any of the Greenlandic walrus processing debris, and suggests a later stage of ivory working in which the extracted tusk is sub-divided for carving or inlay production. The Gásir walrus ivory fragment thus seems to reflect not the initial process of tusk extraction from a recently killed walrus by a hunting community, but a subsequent phase in the conversion of the raw product into material for high quality craftsmanship. Therefore it is less likely to represent the remains of an animal killed nearby than work done on tusks

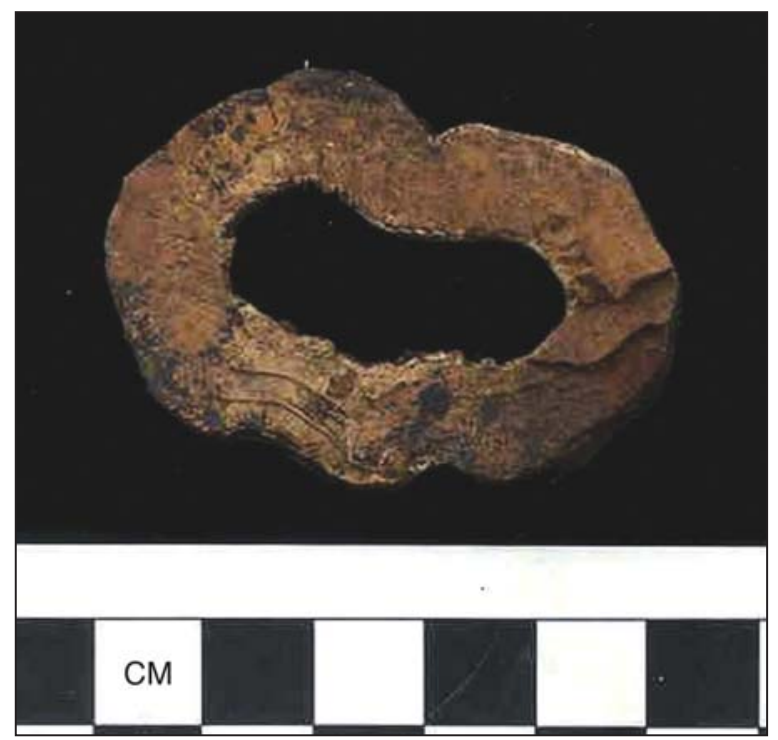

Figure 11. Walrus tusk fragment. Scale in $\mathrm{cm}$. acquired elsewhere (perhaps Greenland), and raises further questions about westwards as well as eastwards overseas connections from Gásir.

\section{Birds}

The majority of Gásir bird bones come from eider ducks, common in summer along the shore of Eyjafjörður today. Guillemot and murre (these species, which have similar habits, cannot be distinguished on most skeletal elements) are also quite regularly found in the various deposits and may have been used as seasonal "crop” in dried form, such as they were prepared in medieval Atlantic Europe (Bond and O’Connor 1999:418). Like the guillemots, the puffin and razorbill are summer migrants present in breeding colonies near the mouth of Eyjafjörður and offshore islands. These auk-family sea birds were widely consumed in Atlantic Europe, including Iceland (i.e., Bárðarsson 1987:92), and their presence in the Gásir deposits probably provides no significant cultural or economic marker. The swan bones are also socially equivocal-in many parts of Europe (notably in medieval England), swans were "royal" birds and their consumption was restricted to the high nobility. In Iceland, migratory swans were occasionally, but not commonly, taken from first settlement onwards, and their bones appear in sites of lower as well as higher status. It is possible that the consumption of swan meat at Gásir carried a different social message to the visiting merchants and their Icelandic customers. Since there is only one specimen of the swan present in the Gásir archaeofauna, the consumption of this large bird may be sporadic rather than a frequent occurrence. Less ambiguously embedded in medieval hierarchical sumptuary animal rankings are the bones of two gyrfalcon (probably from different individuals, contexts 1632 and 756), as these were falconry birds of the highest rank and were reserved as royal gifts. In 1185, Giraldus Cambrensis ( in Forester's translation 2001:34) writes about a noble falcon from Norway that killed King Henry's hawk, which may have stirred his interest in these birds of prey.

\section{Marine Fish}

Fish remains at Gásir account for more than half of the total identified archaeofauna (Table 4). A

Table 4. Total identified archaeofauna.

\begin{tabular}{lcr} 
& Absolute number & Percent \\
\hline Total mammals $^{\mathrm{A}}$ & 4844 & 43.15 \\
Total fish & 6117 & 54.49 \\
Total birds & 179 & 1.59 \\
Total molluscs & 86 & 0.77
\end{tabular}

${ }^{\mathrm{A}}$ Including land and marine mammals. 
large proportion of these fish bones were fragmented beyond element or species association, but the 1745 identifiable fragments of fish bone from Gásir, like most medieval Icelandic archaeofauna, are dominated by fish of the cod family (Gadidae).

In the early Viking Age pre-commercial period of dried fish production and exchange, a wide range of gadid species were dried and exchanged, but one signature of the onset of full-scale commercialization and international fish trade was a specialization on the Atlantic codfish (Gadus morhua), the bones of which tend to dominate the midden contents of major fish-producing sites after ca AD 1100 (Perdikaris 1999, Perdikaris and McGovern 2007, Perdikaris et al. 2004). However, even after the commercial focus upon single species (and standardization on an acceptable size range for individuals), fishing communities tended to provision themselves with now-untradeable by-catch of related gadids (haddock in Iceland, saithe in the Northern and Western Isles; Perdikaris and McGovern 2008), as well as smaller cod not suitable for drying. Since the production of round-dried stockfish requires near-freezing temperatures, the Icelandic medieval commercial fishery (like that of arctic Norway) was in winter, so the Gásir site occupied in summer could not have been involved directly in stockfish production. Any fish shipped through the market to Europe had to have been produced elsewhere. As Figure 12 indi- cates, the proportion of identified gadid fish species present at Gásir do not resemble the cod-dominated signatures of the nearly contemporary fishing sites of Gjögur and Akurvík in the West Fjords (Amundsen et al. 2005, Krivogorskaya et al. 2005), but rather the haddock-rich inland "consumer" sites of Viking Age Mývatn (Hofstaðir and Sveigakot; McGovern et al. 2006). This pattern suggests that the Gásir seasonal settlement was not being cheaply provisioned with dried cod produced in the previous winter from fishing sites like Akurvík, nor were the Gásir residents simply consuming part of the dried cod which may have been a proportion of the Icelandic bulk goods being exported from Gásir. Sturlunga Saga (dating to the mid- $13^{\text {th }}$ century) mentions a farmer who came to Gásir from Siglunes, bringing with him a boatload of fish to trade with the people who lived further inland (Vigfusson 1878).

Initial analysis of the distribution of gadid skeletal elements from the first seasons of excavation at Gásir produced a skeletal pattern lacking most head bones and upper vertebrae, a signature normally associated with the consumption of dried (headless) cod (Krivogorskaya et al. 2005). However, expanded open-area excavation later revealed context 2076, a pit fill associated with what we now suspect to be a fishmonger's shop.

Figure 13 displays the percentages of premaxilla (one of the jaw bones) vs. cleithrum (large bone

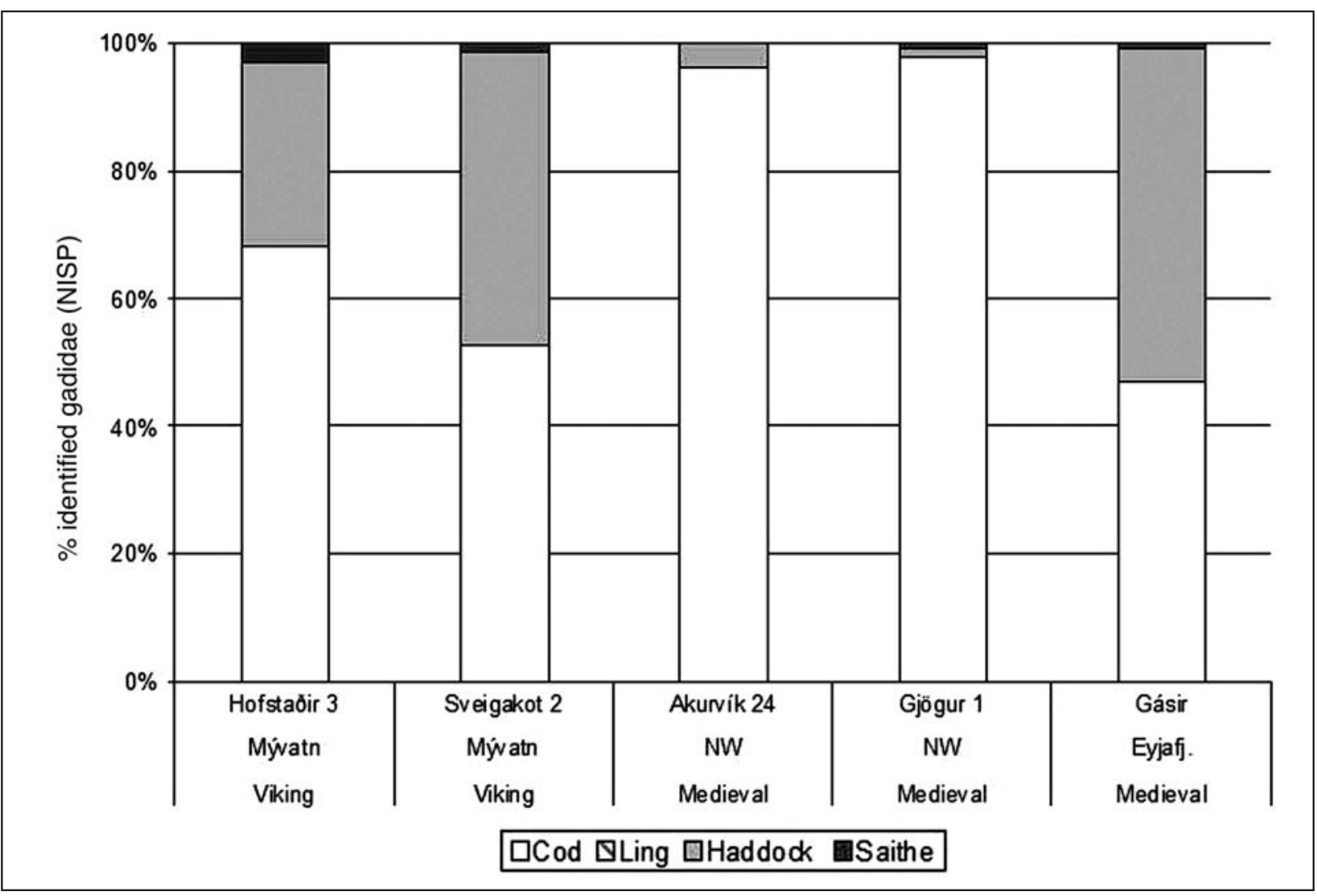

Figure 12. Relative proportions of cod family fish bones from inland “consumer” sites (Hofstaðir, Sveigakot) and two coastal medieval fish "producer” sites in northwest Iceland (Akurvík, Gjögur) in comparison with Gásir. 
found in the pectorial region) bone element ratios for the Gásir gadids. The cleithrum travels with the preserved fish along with varied amounts of the vertebral column, and tends to disproportionately accumulate at consumer sites (Perdikaris and McGovern 2007, 2008). The premaxilla is normally discarded at the point of fish cleaning and preparation for drying or consumption, and thus tends to accumulate differentially at fish-producing sites such as Akurvík (Amundsen et al. 2005). Context 2076 pit fill displays just such a fish-processing pattern: substantial amounts of skull and cranial fragments, including the premaxilla, producing a classic "producer" profile. The rest of the site has produced a surplus of cleithra and vertebral elements in a consumer profile, apparently not because the visiting merchants were eating hard, dried cod, but because they were getting their mix of freshcaught cod and haddock freshly butchered from a vendor on site. As illustrated in Figure 13, when the 2076 pit fill elements are combined with the rest of the site archaeofauna, the proportion of these paired elements matches the 50:50 ratio in a live fish. This "reassembly" of the heads and bodies of the gadids found in the same phase combined with the haddockrich species mix at Gásir suggests provisioning with fresh-caught fish taken from the nearby fjord during the summer trading season (as well as indicating the advantages of an open-area excavation over narrow column samples for zooarchaeological interpreta- tion). It may not be too far-fetched to assume that at least some of the fish consumed at Gásir only traveled within the market place.

\section{Freshwater Fish}

The bones of freshwater salmonids, probably all Brown trout (Salmo trutta), were rare, with only 19 specifiable vertebral elements recovered during flotation. Gásir lies at the Hörgá River estuary, which may have been the source of these freshwater fish, though many clear-running streams in the region have good trout fishing, and smoked trout remains a local delicacy today.

\section{Craft-working Materials}

The walrus tusk fragment illustrated above was most likely brought onto the site as an extracted but unworked tusk, as there is no evidence of butchered walrus post cranial remains or the characteristic maxillary fragments remaining from tusk extraction that are prevalent in Greenlandic collections (McGovern 1985). The nature of the few Gásir horse bone fragments indicates craft-working activities rather than horse-meat consumption, as many elements have tool marks suggesting the extraction of bone raw material from the dense lower limb bones.

Except for the porpoise-size whales, the majority of whale bones found at Gásir bear marks that

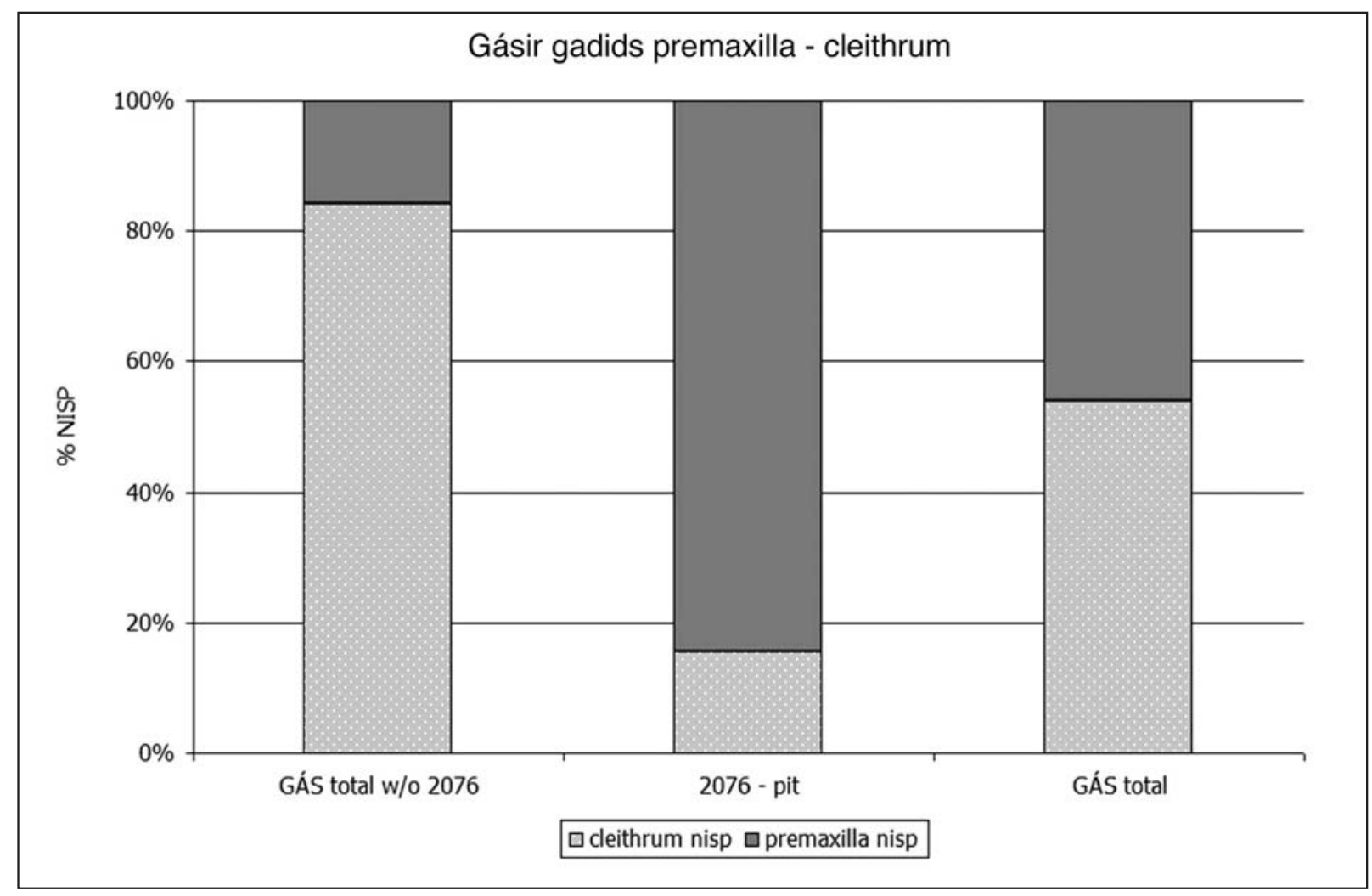

Figure 13. Gásir gadids: comparison of premaxilla vs. cleithrum. 
derive from bone working. A substantial number of cut-marked cattle horn cores have been recovered from several contexts, and these are most likely to be understood as horn craft-working debris. The Gásir archaeofauna thus suggests that the seasonal trading center was not just a marketplace or warehousing center, but also saw substantial craft work aimed at production and finishing of bone and ivory items for local sale or for shipment to Europe.

\section{Foodways and Ethnicity}

Beginning around AD 1150-1200, a method for extracting the marrow from the metapodials (lower leg bones) of sheep and goats spread into several North Atlantic communities, including the Shetlands, Faroes, and Iceland (but not Greenland) using the bi-perforation technique (Bigelow 1985). This method requires opening two circular holes at each end of the metapodial bone and sucking out the rich marrow rather than splitting the bone open to extract the marrow. This marrow-extraction technique avoids bone splinters in the marrow produced by the earlier Viking Age pattern of longitudinal splitting, and has the advantage of retaining a very usefully shaped bone nearly intact for tool use. By the later medieval period, nearly all sheep metapodials in all Icelandic archaeofauna were bi-perforated, and split metapodials are exceedingly rare (by early modern times, a folk belief held that splitting metapodials at meals would cause live sheep to break legs in the same place). In England and Continental Europe, this technique remained unknown, and Late Medieval diners continued to split sheep and goat metapodials in the old fashion. Table 5 presents the proportions of split vs. bi-perforated caprine metapodials from the Gásir collection, documenting the overwhelming use of splitting rather than bi-perforation in marrow extraction. In an Icelandic farm site of the $14^{\text {th }}-15^{\text {th }}$ century, one would expect to see these proportions reversed. The later medieval farmsteads at Stóraborg and Bessastaðir have a large proportion of bi-perforated caprine metapodials (Amorosi 1996). Does the low frequency of bi-perforation reflect non-Icelandic ethnic origins of the at least some of the residents of Gásir?

\section{Discussion}

Gásir thus presents an overall picture of a wealthy, socially differentiated community capable

Table 5. Caprine metapodials.

\begin{tabular}{lcccc} 
& Bi-perforated & Split & Other & Total \\
\hline Count & 8 & 36 & 11 & 55 \\
$\%$ & 14.55 & 65.45 & 20.00 & 100 \\
\hline
\end{tabular}

of expressing its prosperity, piety, and solidarity in the construction of an impressively large church and the organization of a substantial provisioning effort that provided diners with tender beef and lamb, fresh fish, and perhaps the occasional swan and porpoise. Gásir was not simply a warehousing center, but also saw a range of craft activities and potentially the final finishing of walrus ivory acquired elsewhere. Inter-cultural contacts are hinted at by a mix of foodways, exotic imported pets, and the deployment of locally rare drinking vessels (which may have helped to lead the Möðruvellir monks astray). Perhaps most importantly, interdisciplinary investigations indicate that Gásir by the $14^{\text {th }}$ century had an impact on its hinterland, although the extent of that impact is not yet known. Even in the winter season, the great timber church would have been widely visible as a land- and sea-mark, and it would appear that at least some Icelandic farmers were involved in raising cattle and caprines with the specific thought of delivering them to the trading site. While we know only very little about the regional economic and subsistence structures, additional research now underway at the Möðruvellir and other sites in Eyjafjörður may help better understand the socio-cultural forces at work at Gásir (Harrison and Roberts 2007).

\section{Acknowledgments}

The authors wish to acknowledge the financial and logistic support for the excavation at Gásir from the Museum of Akureyri. Special thanks go to the Icelandic Millennium fund (Kristnihátíðarsjóður) and Ríkissjóður (National Icelandic Government funding). R. Harrison gratefully acknowledges the support from the Leifur Eiriksson Fund, the Leverhulme Trust Program "Landscapes circum-Landnám," the US National Science Foundation Arctic Social Sciences Program (Grants OPP AC 0732327, BCS 0001026, OPP 402900001 and OPP ARC 0809033) and the CUNY Doctoral Program in Anthropology. She would also like to thank Sophia Perdikaris, Thomas H. McGovern, Orri Vésteinsson, Mjöll Snæsdóttir, and Jim Woollett, for their sustained support and help in field and lab and Seth Brewington for his help with faunal analysis from the Gásir 2003 season. Sampling and analysis of the sulphur materials has been supported by The Leverhulme Trust Programme "Landscapes circum-Landnám," by The British Academy and by the European Synchrotron Radiation Facility (ESRF) beamtime award ME-826 on beamline ID18F. Amanda Thomson and Ian Simpson of the University of Stirling kindly assisted with the sulphur material fieldwork.

\section{Literature Cited}

Adamson, M.W. 2004. Food in Medieval Times. Greenwood Publishing Group, Westport, CT, USA

Adderley, W.P., and I.A. Simpson. 2005. Early-Norse home-field productivity in the Faroe Islands. Human Ecology 33:711-736. 
Adderley, W.P., and I.A. Simpson. 2006. Soils and palaeoclimate-based evidence for irrigation requirements in Norse Greenland. Journal of Archaeological Science 33:1666-1679.

Adderley, W.P., I.L. Alberts, I.A. Simpson, and T.J. Wess. 2004a. Fish bone materials in archaeological soils and sediments: Characterisation of materials through synchrotron X-ray diffraction analyses and micromorphological analysis in thin-section. Journal of Archaeological Science 31:1215-1224.

Adderly, W.P., I.A. Simpson, R. Rarrett, H.M. Roberts, and T. Wess. 2004b. Gásir and early sulphur trade in northern Europe: Analyses of processing practices and trade. Pp. 60-1, In H.M. Roberts et al. (Eds.). Gásir: An Interim Report. Fornleifastofnun Íslands FS23801075. Reykjavík, Iceland.

Amorosi, T. 1996. Zooarchaeology and global change in Iceland. Ph.D. Dissertation. Hunter College, CUNY, New York, NY, USA.

Amorosi, T., P.C. Buckland, G. Olafsson, J.P. Sadler, and P. Skidmore. 1992. Site status and the palaeoecological record: A discussion of the results from Bessastadir, Iceland. Pp. 169-192, In C. Morris and J. Rackham (Eds.). The Archaeology of the Norse North Atlantic. Archetype Publications, Glasglow, UK.

Amundsen, C., S. Perdikaris, T.H. McGovern, Y. Krivogorskaya, M. Brown, K. Smiarowski, S. Storm, S. Modugno, M. Frik, and M. Koczela. 2005. Fishing booths and fishing strategies in Medieval Iceland: An archaeofauna from the of Akurvík, northwest Iceland. Environmental Archaeology 10:2.

Ascough, P.L., G.T. Cook, M.J. Church, A.J. Dugmore, S.V. Arge, and T.H. McGovern. 2006. Variability in North Atlantic marine radiocarbon reservoir effects at c. AD 1000. Holocene 16(1):131-136.

Bárðarson, H.R. 1987. Birds of Iceland. Self-published by author, Reykjavík, Iceland.

Barrett, J.H., and M.P. Richards. 2004. Identity, gender, religion, and economy: New isotope and radiocarbon evidence for marine resource intensification in early historic Orkney, Scotland. European Journal of Archaeology 7:249-271.

Barrett, J.H., A.M. Locker, and C.M. Roberts. 2004. "Dark Age economics” revisited: The English fish-bone evidence AD 600-1600. Antiquity 78(301):618-636.

Bigelow G.F. 1985. Sandwick Unst and the Late Norse Shetlandic Economy. Pp. 95-127, In B. Smith (Ed.). Shetland Archaeology: New Work in Shetland in the 1970s. Shetland Times Press, Lerwick, Shetland Islands, Scotland, UK.

Boessneck, J. 1969. Osteological differences between sheep (Ovis aries Linne) and goats (Capra hircus Linne). Pp. 331-358, In D. Brothwell and E. Higgs (Eds.). Science in Archaeology. Thames and Hudson, London, UK.

Bond, J.M., and T.P. O'Connor. 1999. Bones from Medieval Deposits at 16-22 Coppergate and Other Sites in York. A book in the series, The Archaeology of York: The Animal Bones 15/5 YAT and CBA (edited by Sue Stallibrass). University of Liverpool, Liverpool, UK.

Brewington, S., R. Harrison, C. Amundsen, and T.H. McGovern. 2004. An early 13th-century Archaeofauna from Steinbogi, Mývatn District, Northern Iceland. NORSEC Laboratory, CUNY, New York, NY, USA. Report No. 11.
Bronk, R. 2003. OxCal v.3.9. Available online at http: //www.units.ox.ac.uk/departments/rlaha/orau/06_ ind.html. Date accessed: March 2006.

Bruun, D., and F. Jónsson. 1908. Det gamle Handelssted Gásar. Videnskabernes Selskabs Forhandlinger: No.3. Kobenhavn, Denmark.

Cambrensis,G., and T. Forester (Translator). 2001. The Conquest of Ireland. In Parentheses Publications, Medieval Latin Series, Cambridge, ON, Canada.

Capelle, T. 1982. Untersuchungen auf dem Mittelalterlichen Handelsplatz Gautavík, Island. Köln, Rheinland Verlag, Koln/Cologne, Germany.

Christiansen, D.V. 2002. Handel og kommunikation i Nordatlanten. Rapport om prøveundersøgelserne på den formodede atlanthavn, Sandhavn ved Maakkarneq, Nanortalik kommune, sommeren 2001. SILA-Nationalmuseets Center for Grønlandsforskning, Copenhagen, Denmark. Feltrapport 3, Januar 2002.

Clarke, H. 1984. Archaeology of Medieval England. Blackwell Publications, Copenhagen, Denmark.

Driesch, A. 1976. A guide to the measurement of animal bones from archaeological sites. Peabody Museum Bulletin 1, Peabody Museum of Archaeology and Ethnology, Harvard University, Cambridge, MA, USA.

Driesch, A., and J. Boessneck. 1974. Kritische Anmerkungen zur wiederristhöhenberechnung aus längenmaßen vor: Und frühgeschichtlichr Tierknochen. Säugetierkundliche Mitteilungen 22:328-348.

Dugmore, A.J., D.M. Borthwick, M.J. Church, A. Dawson, K.J. Edwards, C. Keller, P. Mayewski, T.H. McGovern, K.-A. Mairs, and G. Sveinbjarnardóttir. 2007. The role of climate in settlement and landscape change in the North Atlantic islands: An assessment of cumulative deviations in high-resolution proxy climate records. Human Ecology 35:169-178.

Durrenberger, P., and G. Pálsson (Eds.). 1989. The Anthropology of Iceland. University of Iowa Press, Iowa City, IA, USA.

Edvardsson, R., and T.H. McGovern. 2005 Archaeological excavations at Vatnsfjörður 2003-04 Archaeologica Islandica 4:16-31.

Edvardsson, R., S. Perdikaris, T.H. McGovern, N. Zagor, and M. Waxman. 2004. Coping with hard times in NW Iceland: Zooarchaeology, History, and Landscape Archeology at Finnbogastaðir in the $18^{\text {th }}$ Century. Pp. 29-46, In G. Lucas (Ed.). Archaeologica Íslandica, Volume 3. Institute of Archaeology, Reykjavík, Iceland.

Eldjárn, K., and A. Friðriksson. 2000. Kuml og Haugfé: úr heiðnum sið á Íslandi. Mál og menning, Reykjavík, Iceland.

Enghoff, I.B. 2003. Hunting, fishing, and animal husbandry at the Farm Beneath the Sand, Western Greenland: An archaeozoological analysis of a Norse farm in the Western Settlement. Meddelser om Grønland. Man and Society 28. SILA, Copenhagen, Denmark.

Foote, P., and D. Wilson. 1970. The Viking Achievement. Sidgwick and Jackson, London, UK.

Gelsinger, B.E. 1981. Icelandic Enterprise: Commerce and Economy in the Middle Ages. University of South Carolina Press, Columbia, SC. 
Grant, A. 1982. The use of tooth wear as a guide to the age of domestic ungulates. Pp. 91-108, In B. Wilson, C. Grigson, and S. Payne (Eds.). Ageing and Sexing Animal Bones from Archaeological Sites, BAR British Series 109, Oxford, UK.

Grayson, D.K. 1984. Quantitative Zooarchaeology. Academic Press, Orlando, FL, USA.

Hall, R.A., and K. Hunter-Mann. 2004. Medieval Urbanism in Coppergate: Refining a Townscape, The Medieval Walled City Northeast of the Ouse. The Archaeology of York. Council for British Archaeology York, UK.

Halstead, P. 1998. Mortality models and milking: Problems of uniformitarianism, optimality, and equifinality reconsidered. Anthropoxoologica 27:3-20.

Harcourt, R.A. 1974. The dog in prehistoric and early historic Britain. Journal of Archaeological Science 1: 151-175.

Harrison, R. 2006. Interim report of animal bones from the 2005 excavations at Gásir, Eyjafjörður, northern Iceland. NORSEC Zooarchaeology Laboratory Reports No. 28, CUNY, New York, NY, USA.

Harrison, R., and H.M. Roberts. 2007. The midden at Möðryvellir 2007: Preliminary excavation report of the Möðryvellir midden, 2007. Fornleifastofnun Íslands FS365-006382, Reykjavík, Iceland.

Hastrup, K. 1985. Culture and History in Medieval Iceland: An Anthropological Analysis of Structure and Change. Oxford University Press, Oxford, UK.

Hastrup, K. 1990. Nature and Policy in Iceland, 14001800: An Anthropological Analysis of History and Mentality. Clarendon Press, Oxford, UK.

Hersteinsson, P. 1989. Population genetics and ecology of different colour morphs of Arctic foxes Alopex lagopus in Iceland. Finnish Game Research 46:64-78.

Jóhannesson, J. 1974. A History of the Old Icelandic Commonwealth: Íslendinga Saga. Translated by Haraldur Bessason. University of Manitoba Press, Winnipeg, MB, Canada.

Jóhannesson, J., M. Finbogason, and K. Eldjárn (Eds.). 1946. Sturlunga Saga, Volume 1. Sturlunguútgafan, Reykjavik, Iceland.

Karlsson, G. 2000. Iceland's 1100 Years: History of a Marginal Society. Hurst and Co., Ltd., London, UK.

Kennedy, C.J., J.C. Hiller, D. Lammie, M. Drakopoulos, M. Vest, M. Cooper, W.P. Adderley, and T.J. Wess. 2004. Microfocus X-ray diffraction of historical parchment reveals variations in structural features through parchment cross-sections. Nano Letters 4: 1373-1380.

Kramer, G.W. 2001. The Firework Book: Gunpowder in Medieval Germany. The Journal of the Arms and Armor Society 17(1):89.

Kristjánsson, L. 1985-88. Íslenzkir Sjávarhættir. Bókaútgáfa Menningarsjóðs, Reykjavík, Iceland.

Kristjönudóttir, I.S. 2005. Hof and Hólar in Hjaltadalur: A Study of Central farms in Hjaltadalur in Skagafjörður, Iceland in Viking and Early Medieval Times. Uppsala Universitet, Uppsala, Sweden

Krivogorskaya, Y., S. Perdikaris, P. Latiperra, and T.H. McGovern. 2003. FISHBONE 3.1: A digital aid to identification and quantification of North Atlantic fish bones. CUNY Northern Science Center and North Atlantic Bioculural Organization, New York, NY. Also available online at the Brooklyn College website.
Krivogorskaya, Y., S. Perdikaris, and T.H. McGovern. 2005. Fish bones and fishermen: The potential of zooarchaeology in the Westfjords, Archaeologica Islandica 4:31-51.

Kutney, G. 2007. Sulfur: History, Technology, Applications, and Industry. ChemTec Publishing, Toronto, ON, Canada.

Mainland, I. 2006. Pastures lost? A dental microwear study of ovicaprine diet and management in Norse Greenland. Journal of Archaeological Science 33: 238-252.

Mainland, I., and Halstead, P. 2005. The economics of sheep and goat husbandry in Norse Greenland. Arctic Anthropology 43:103-120.

McGovern, T.H. 1985. The Artic frontier of Norse Greenland. Pp. 275-323, In S. Green and S. Perlman (Eds.). The Archaeology of Frontiers and Boundaries. Academic Press, London, UK.

McGovern, T.H. 1990. The archaeology of the Norse North Atlantic. Annual Review of Anthropology, 19: 331-351.

McGovern, T.H., and S. Perdikaris. 2002. Preliminary report of animal bones from Hrísheimar northern Iceland. Report on file at Fornleifastofnun Íslands and National Museum of Iceland, Reykjavík, Iceland.

McGovern, T.H., and S. Perdikaris. 2007. Preliminary Report of Animal Bones from Selhagi, Mývatn District, Northern Iceland. NORSEC Zooarchaeology Laboratory Reports No. 5 Draft. CUNY, New York, NY, USA.

McGovern T.H., T. Amorosi, S. Perdikaris, and J.W. Woollett. 1996. Zooarchaeology of Sandnes V51: Economic change at a Chieftain's Farm in West Greenland. Arctic Anthropology 33(2)94-122.

McGovern, T.H., O. Vésteinsson, S. Perdikaris, and C. Amundsen. 2004. Zooarchaeology of Landnám: $9^{\text {th }}-11^{\text {th }}$-century midden deposits at Sveigakot, northern Iceland, NORSEC Zooarchaeology Laboratory Reports No. 18, CUNY, New York, NY, USA.

McGovern, T.H., S. Perdikaris, A. Einarsson, and J. Sidell. 2006. Coastal connections, local fishing, and sustainable egg harvesting: Patterns of Viking Age inland wild resource use in Mývatn District, northern Iceland. Environmental Archaeology 11.1:102-128.

McGovern, T.H., O. Vésteinsson, A. Fridriksson, M. Church I. Lawson, I.A. Simpson, A. Einarsson, A. Dugmore, G. Cook, S. Perdikaris, K.J. Edwards, A.M. Thomson, W.P. Adderley, A. Newton G. Lucas, R. Edvardsson, O. Aldred, and E. Dunbar. 2007. Landscapes of settlement in northern Iceland: Historical ecology of human impact and climate fluctuation on the millennial scale. American Anthropologist 109:27-51.

Melsteð, B.Th. 1895. Hverjir ráku verzlun milli Íslands og annara landa á dögum hins ílsenzka pjóðveldis? Búnaðarrit IX:52-80.

Melsteð, B.Th. 1907-15. Ferðir, Siglingar og Samgöngur Milli Íslands og Annara Landa á Dögum pjóðveldisins. Safn til Sögu Íslands og Islenzkra Bókmennta að Fornu og nýju IV. Kaupmannahöfn og. Hið íslenzkra bókmentafélag, Reykjavík, Iceland

Melsteð, B.Th. 1916-30. Íslendinga saga I-III. Hið Íslenzka Bókmenntafélagi, Copenhagen, Denmark.

Morison, S.E. 1971. The European Discovery of America: The Northern Voyages, 500-1600 AD. Oxford University Press, New York, NY, USA. 
Müldner, G. and M.P. Richards. 2007. Diet and diversity at later medieval fishergate: The isotopic evidence. American Journal of Physical Anthropology 134(2): 162-174.

Mulville J., J.M. Bond, and O. Craig. 2005. The white stuff: Milking in the outer Scottish Isles. Pp. 167-182, In J. Mulville and A.K. Outram (Eds.). The Zooarchaeology of Fats, Oils, Milk, and Dairying. Oxbow, Oxford, UK.

Munn, W.A. 1936. John Cabot's landfall. Lecture to Newfoundland Historical Society. Newfoundland Quarterly 36:1.

Museum of London. 1994. Archaeological Site Manual. London, UK.

North Atlantic Biocultural Organization (NABO) Zooarchaeology Working Group. 2004. NABONE Zooarchaeological Recording Package, 8th Edition. CUNY, New York, NY, USA.

Ogilvie, A. 1991. Climate changes in Iceland AD 865 to 1598. In G. Bigelow (Ed.). The Norse of the North Atlantic. Acta Archaeologica Volume 61. Munkgaard, Lobenhaven, Denmark.

Ogilivie, A.E.J., J.M. Woollett, K. Smiarowski, J. Arneborg, S. Toelstra, A. Kuijpers, A. Pálsdóttir, and T.H. McGovern. In prep. Seals and sea ice in medieval Greenland. To be submitted to the Journal of the North Atlantic.

Ólafsson, G. 1991a. Recent archaeological investigation at Bessastaðir, southwestern Iceland. Pp. 108-115, In G.F. Bigelow (Ed.). The Norse of the North Atlantic: Archaeology, Biology, and Cultural Ecology of the Medieval Scandinavian Settlement. Acta Archaeologica Volume 61. Munkgaard, Lobenhaven, Denmark

Ólafsson, G. 1991b. Fornleifarannsoknir á Bessastöðum 1987-1989. Félagið Ingólfur, Landnám Ingólfs 4, Reykjavík, Iceland.

Pálsdóttir, A.H. 2005. Segðu mér sögu af seli: Fornleifafrædileg úttek á íslenskum seljum. Lokaverkefni frá Háskóla Î́slands, Reykjavík, Iceland.

Pálsdóttir, A.H. 2006. Archaeofauna from Skriðuklaustur, East-Iceland: Preliminary report, 2002 excavation season. NORSEC Zooarchaeology Laboratory Reports No. 30. CUNY, New York, NY, USA.

Perdikaris, S. 1999. From chiefly provisioning to commercial fishery: Long-term economic change in Arctic Norway. World Archaeology 30(3):388-402.

Perdikaris, S., and T.H. McGovern. 2007. Walrus, cod fish, and chieftains : Intensification in the Norse North Atlantic. Pp.193-216, In T.L. Thurston and C.T. Fisher (Eds.). Seeking A Richer Harvest: The Archaeology of Subsistence Intensification, Innovation, and Change. Springer Science and Business Media, New York, NY, USA.

Perdikaris, S., and T.H. McGovern. 2008. Codfish and kings, seals and subsistence: Norse marine resource use in the North Atlantic. Pp. 157-190, In T. Rick and J. Erlandson (Eds.). Human Impacts on Marine Environments, UCLA Press Historical Ecology Series, Los Angeles, CA, USA.

Perdikaris, S., C. Amundsen, and T.H. McGovern. 2002. report of animal bones from Tjarnargata 3C, Reykjavík, Iceland. NORSEC Zooarchaeology Laboratory Reports Number 1, CUNY, New York, NY.
Perdikaris, S., T.H. McGovern, Y. Krivogorskaya, and M. Waxman. 2004 Early modern fisher-farmers at Finnbogastaðir and Gjögur in northwest Iceland. Pp.139-144, In R. Gonzales (Ed.). Presence of the Archaeo- ichthyology in Mexico. ICAZ Fish Remains Working Group 2003, Guadalajara, Mexico.

Prilloff, R.-J. 2000. Tierknochen aus dem mittelalterlichen Konstanz: Eine archäozoologische Studie zur Ernährungswirtschaft und zum Handwerk im Hochund Spätmittelalter. Theiss, Stuttgart, Germany.

Reichstein, H. 2002. Vergleichende betrachtungen zur nahrungsversorgung der bewohner von Haithabu und Schleswig. Pp. 169-180, In Brandt et al. (Eds.). Haithabu und die frühe Stadtentwicklung in Nördlichen Europa. Wachholtz Verlag, Neumünster, Germany.

Reitz, E.J., and E.S. Wing. 1999. Zooarchaeology. Cambridge University Press, Cambridge, UK.

Roberts, H.M. et al. 2002a. Fornleifarannsókn á Gásum/ Archaeological research at Gásir, 2001. An interim report/Framvinduskýrsla. Fornleifastofnun 1́slands FS163-01071, Reykjavík, Iceland.

Roberts, H.M. et al. 2002b. Archaeological investigations at Gásir 2002 : A preliminary report. Fornleifastofnun Íslands FS180-01072, Reykjavík, Iceland.

Roberts, H.M. et al. 2004. Excavations at Gásir 2003: An interim report. Fornleifastofnun Íslands FS238-01075. Reykjavík, Iceland.

Roberts, H.M. et al. 2005. Gásir 2004: An interim report. Fornleifastofnun Íslands FS194-01073. Reykjavík, Iceland.

Roberts, H.M. et al. 2006. Excavations at Gásir 20012006 : A preliminary report. Fornleifastofnun Íslands FS335-01079. Reykjavík, Iceland.

Roberts, H.M., L.B. Pálsdóttir, et al. 2006. Excavations at Gásir 2005: An interim report/Framvindskýrsla. Fornleifastofnun ĺslands FS312-01078. Reykjavík, Iceland.

Robinson, D., and B. Aaby. 1994. Pollen and plant macrofossil analyses from the Gedesby ship: A medieval shipwreck from Falster, Denmark. Vegetation History and Archaeobotany 3:167-182.

Sigurðsson, J.V. 1999. Chieftains and Power in the Icelandic Commonwealth (Translation by Jean Lundskær-Nielsen). Odense University Press, Viking Collections XII, Odense, Denmark.

Simpson, I.A., W.P. Adderley, G. Guðmundsson, M. Hallsdóttir, M.A. Sigurgeirsson, and M. Snæsdóttir. 2002. Land management for surplus grain production in early Iceland. Human Ecology 30:423-443.

Smiarowski, K., A. Palsdottir, and T.H. McGovern. 2007. Preliminary assessment report of the archaeofauna from KNK 203 (E 74), a Norse farm in the Eastern Settlement, Greenland. NORSEC Zooarchaeology Laboratory Reports No 36. CUNY, New York, NY, USA.

Steingrímsson, S., Ó. Halldórsson, and P. Foote (Eds,). 2003. Biskupa sögur, Volume 1. Íslenzk fornrit 15. Hið Íslenzka Fornritafélag, Reykjavík, Iceland.

Storm, G. 1888. Islandske Annaler indtil 1578. Gröndal and Söns Bogtrykkeri. Christiania, Denmark. 
Szabo, V.E. 2005. "Bad to the bone?” The unnatural history of monstrous medieval whales. Traders, Saints, and Pirates: The Sea in Early Medieval Northwestern Europe. A Journal of Early Medieval Northwestern Europe Issue Number 8. Available online at http: //www.mun.ca/mst/heroicage/issues/8/szabo.html. Accessed December 2008.

Thomas, R. 2005. Changing attitudes towards pets in medieval and post-medieval England in BAR S1410 2005: Just skin and bones? Pp. 95-104, In A. Pluskowski (Ed.). New Perspectives on Human-Animal Relations in the Historical Past. Archaeopress, Oxford, UK.

Tinsley, C.M., and T.H. McGovern. 2002. Zooarchaeology of Aðalstræti 14-16, 2001: Report of the Viking period animal bones. NORSEC Zooarchaeology Laboratory Reports No. 2. New York, NY, USA.

pórðarson, B. 1957. Íslenzkir Fálkar. Hið Íslenzka Bókmenntafélag, Reykjavík, Iceland.

porkelsson, M. 2004. Í Hvalfirði: Midaldahöfn og hlutverk hennar. Háskóli Íslands. M.A. Thesis. University of Iceland, Reykjavík, Iceland.

porláksson, H. 2008. Historical background: Iceland 8701400. Pp. 136-154, In R. McTurk (Ed.). A Companion to Old Norse-Icelandic Literature and Culture, Second Edition. Blackwell Publishing, Oxford, UK.

poroddeon, P. 1919. Lýsing Íslands. Hinu Íslenzka Djóðvinafjelagi, Copenhagen, Denmark.

porsteinsson, B. 1970. Enska öldin í sögu Íslendinga. Mál og Menning, Reykjavík, Iceland.

porsteinsson, B. 1972. "Svovl.” Kulturhistorisk Leksikon for Nordisk Middelalder XVII: 589-91.

Vésteinsson, O. 2000. The Christianization of Iceland: Priests, Power, and Social Change 1000-1300. Oxford University Press, Oxford, UK.

Vésteinsson, O. 2004. Icelandic Farmhouse Excavations: Field Methods and Site Choices. Archaeologica Íslandica 3, Reykjavík, Iceland.

Vésteinsson, O. 2006. Central areas in Iceland. Pp. 307-333, In J. Arneborg and B. Grönnow (Eds.). Dynamics of Northern Societies: Proceedings of the SILA/NABO Conference on Arctic and North Atlantic Archaeology. Published by the National Museum of Denmark, Copenhagen, Denmark.

Vesteinsson, O., and T.H. McGovern. In prep. Steinbogi in Mývatnssveit and changing farming strategies in High Medieval Iceland. Paper presented at 2008 Society for American Archaeology meeting Vancouver BC April 2008. To be submitted to Journal of the North Atlantic.

Vésteinsson, O., T.H. McGovern, and C. Keller. 2003. Enduring Impacts: Social and Environmental Aspects of Viking Age Settlement in Iceland and Greenland. Archaeologica Islandica 2, Reykjavik, Iceland.

Vigfusson, G. 1878. Sturlunga Saga, Including the Islendinga Saga of lawman Sturla Thordsson and Other Works. Clarendon Press, Oxford, UK.

Wheeler, A., and A.K.G. Jones. 1989. Fishes. Cambridge University Press, Cambridge, UK.

Wigh, B. 2001. Animal Husbandry in the Viking Age Town of Birka and its Hinterland. A book in the series, Birka Studies: Excavations in the Black Earth 1990-1995. Stockholm, Sweden.
Woollett, J. 2004. Seals and seasonality in northeastern Iceland during the Middle Ages and Early Modern Period, Paper presentation at Dynamics of Northern Societies, a SILA and NABO conference, May 2004. Copenhagen, Denmark. 